\title{
A Review of Battery Materials as CDI Electrodes for Desalination
}

\author{
Yuxin Jiang ${ }^{1}$, Sikpaam Issaka Alhassan ${ }^{1}$, Dun Wei ${ }^{1}$ and Haiying Wang ${ }^{1,2,3, *}$ \\ 1 Department of Environmental Engineering, School of Metallurgy and Environment, \\ Central South University, Changsha 410083, China; brucejiang@csu.edu.cn (Y.J.); \\ alhassansb@csu.edu.cn (S.I.A.); weidun95@csu.edu.cn (D.W.) \\ 2 Chinese National Engineering Center for Control and Treatment of Heavy Metals Pollution, \\ Changsha 410083, China \\ 3 Water Pollution Control Technology Key Lab of Hunan Province, Changsha 410083, China \\ * Correspondence: Haiyw25@csu.edu.cn; Tel.: +86-0731-8883-0511
}

Received: 15 September 2020; Accepted: 19 October 2020; Published: 28 October 2020

\begin{abstract}
The world is suffering from chronic water shortage due to the increasing population, water pollution and industrialization. Desalinating saline water offers a rational choice to produce fresh water thus resolving the crisis. Among various kinds of desalination technologies, capacitive deionization (CDI) is of significant potential owing to the facile process, low energy consumption, mild working conditions, easy regeneration, low cost and the absence of secondary pollution. The electrode material is an essential component for desalination performance. The most used electrode material is carbon-based material, which suffers from low desalination capacity (under $15 \mathrm{mg} \cdot \mathrm{g}^{-1}$ ). However, the desalination of saline water with the CDI method is usually the charging process of a battery or supercapacitor. The electrochemical capacity of battery electrode material is relatively high because of the larger scale of charge transfer due to the redox reaction, thus leading to a larger desalination capacity in the CDI system. A variety of battery materials have been developed due to the urgent demand for energy storage, which increases the choices of CDI electrode materials largely. Sodium-ion battery materials, lithium-ion battery materials, chloride-ion battery materials, conducting polymers, radical polymers, and flow battery electrode materials have appeared in the literature of CDI research, many of which enhanced the deionization performances of CDI, revealing a bright future of integrating battery materials with CDI technology.
\end{abstract}

Keywords: battery materials; CDI electrodes and desalination

\section{Introduction}

With the rapid population growth and industrialization, water pollution and over consumption of energy, the water shortage is becoming a more and more serious problem [1-5]. Though water covers most of the surface of the earth, only a small amount is available for human use [6,7]. Studies have shown that $97.5 \%$ of the total water of the earth is seawater or brackish water, and only $0.4 \%$ of the rest is accessible for use because most of it is stored in the form of ice or under the earth [8-10]. About 700 million people are facing the water shortage crisis and the demand for fresh water is estimated to grow by $50 \%$ by 2025 [11,12]. It is therefore necessary to employ strategies that would mitigate water shortage. As a result, desalination of saline water into fresh water could be a reasonable choice to solve this problem [13-15].

Obtaining a safe and simple method of desalination of saline water with low cost, high efficiency and high recovery has always been the focus of scientists. Several desalination techniques have already been scaled up: multi-effect distillation [16-18], multi-stage flash distillation [19-21], mechanical vapor 
compression [22-24], reverse osmosis desalination [25-27], forward osmosis desalination [28-30], membrane distillation [31-33] and ion-exchange membrane desalination [34-36]. These methods require either strict high energy-consuming operation conditions or expensive membrane cost.

Capacitive deionization (CDI) is a facile, safe, energy-efficient method of desalination with a low cost and a long cycle life without secondary pollution [37-39]. The conception of CDI was raised by Caudle in the 1960s [40]. The traditional CDI system consists of two electrodes at the opposite side of each other in a symmetric way with the saline water in the middle [41]. When a voltage (usually under $1.2 \mathrm{~V}$ to avoid water splitting) was charged, the salt ions would be adsorbed by the electrodes thus producing the desalinated water, and when the system is discharged, the ions would be released into the solution thus forming the concentrated water with the regeneration of the electrodes [42-44]. The working conditions of CDI are mild and safe, and methods of improving anti-fouling properties have been developed [45-48], indicating a great potential in the desalination field [49,50].

However, CDI has a defect that the salt removal capacity is relatively low which hinders the application of the technology [51-53]. The materials used in the CDI system are the core of the technology, and the traditional electrode materials are carbonaceous which possess the properties of high conductivity, high surface area, good cycling ability, structural stability and low cost $[54,55]$. During the desalination process, the salt ions are adsorbed on the surface of the electrode thus forming the electrical double layer with the opposite charge layer on the inner surface of the electrode [56]. The capacitive materials of carbon not only adsorb the oppositely charged ions but also repel the similarly charged ions, leading to the decrease in the charge efficiency and desalination capacity, which is called the co-ion effect $[57,58]$. The salt removal capacity is usually under $15 \mathrm{mg} \cdot \mathrm{g}^{-1}$ due to the limited surface adsorption and the co-ion effect.

From an electrochemical perspective, the capacitive deionization is the process of storing energy in the electrodes, and the subsequent regeneration of the electrodes is the delivery of the energy $[59,60]$. CDI process could be closely related to the behavior of the batteries and supercapacitors $[61,62]$. The batteries usually have larger capacities than supercapacitors because of the redox reactions occurring in the battery electrode materials that enhance the larger scale of charge transfer. There are no clear barriers between battery materials and pseudocapacitive materials because the definitions of them are both based on redox reactions. The materials of rechargeable batteries have been developed very fast recently, with various kinds appearing in the literature with diverse extraordinary electrochemical properties, some of which have already been used in industrial production, indicating a promising future of integrating CDI technology with battery materials.

Battery materials usually share a high theoretical electrochemical capacity, which could improve the desalination capacity of the CDI system $[63,64]$. There are still some aspects that need to be noticed when selecting the battery CDI electrode materials. The electrode is immersed in water during the desalination process, which means the material should be insoluble and hydrophilic thus providing full contact between the ions and materials. Besides, the redox reactions should occur within the water voltage window to prevent water from splitting, and the ions in the water might be hydrated leading to larger sizes, which reveal a more rigorous requirement of the structure of battery materials to avoid the collapse of the conformation during charge and discharge processes.

The usage of battery materials in the CDI process has been a hotspot in desalination research in recent times. Herein we compose a review of the literature on battery materials used as CDI electrodes and their performances to gain a better understanding of the roles battery CDI electrodes are playing. The battery materials used in the CDI system are grouped into different categories according to Figure 1 based on the types of the original batteries and the behaviors of CDI processes. We discuss the progress of CDI battery electrode materials in the order of the corresponding batteries. 


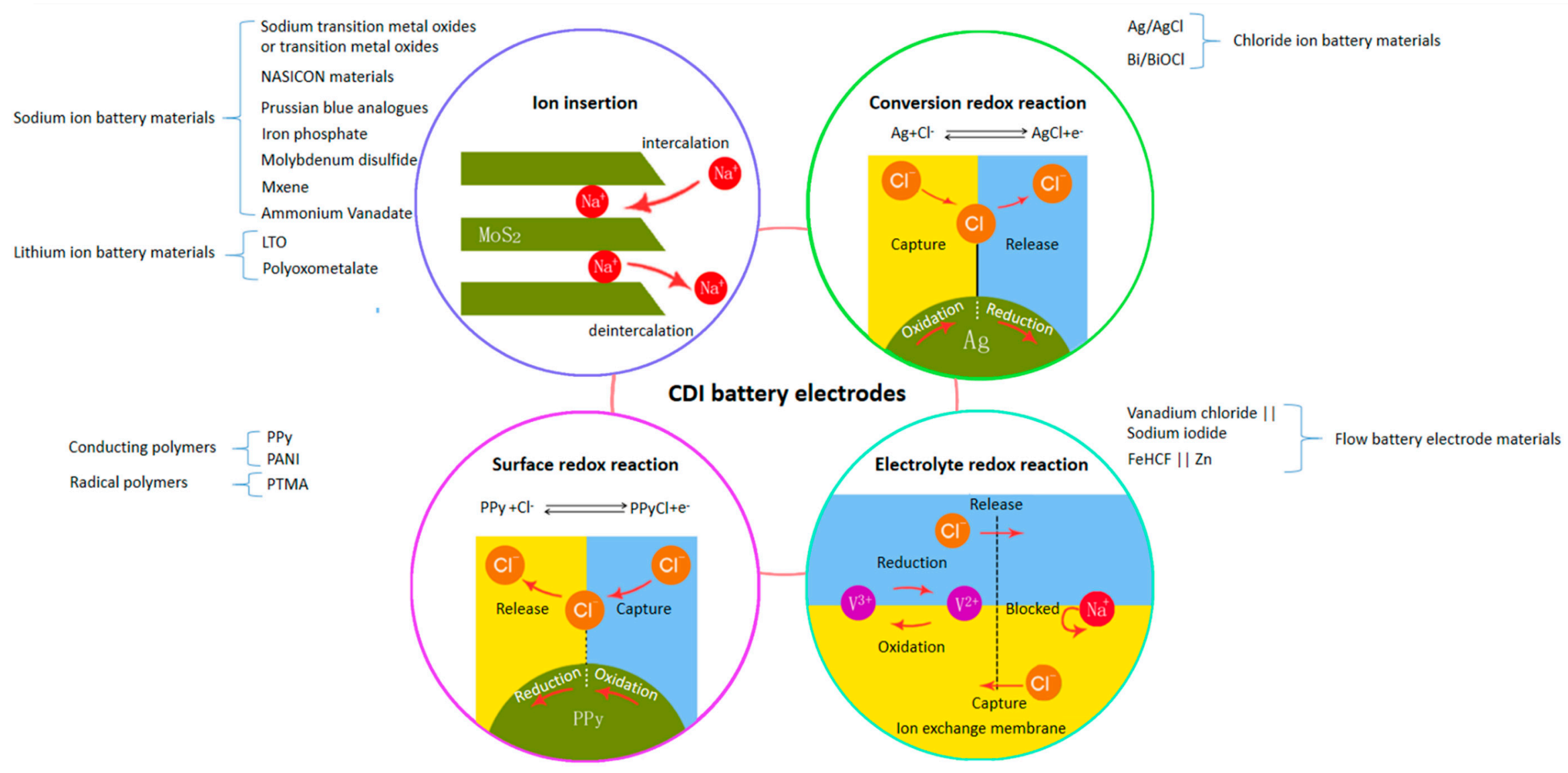

Figure 1. Schematic diagram of an overview of different types of capacitive deionization (CDI) battery electrode materials. 


\section{Na-Ion Battery Materials}

It is very easy to get the idea that the Na-ion battery materials can be very closely related to the CDI process for desalination because of the $\mathrm{Na}^{+}$. In recent years, various Na-ion battery materials have been developed [65-69]. Nevertheless, not all kinds of these materials are suitable for CDI. $\mathrm{CDI}$ processes require the $\mathrm{Na}$-ion battery electrodes to have a voltage plateau just in the voltage window of water [70-72]. Up to now, part of the materials has already been chosen for the CDI desalination and exhibit good performances.

\subsection{Sodium Transition-Metal Oxide and Transition-Metal Oxide}

Sodium transition-metal oxide can be represented as $\mathrm{Na}_{x} \mathrm{M}_{\mathrm{y}} \mathrm{O}_{\mathrm{z}}$, in which $\mathrm{M}$ stands for transition metal elements $(\mathrm{Mn}, \mathrm{Co}$, etc). The valence of the transition metal element could change dramatically when the charged voltage changes, thus allowing the sodium ion intercalation process [73-75]. When the sodium ions are released from the material, the transition-metal oxide is formed, so we conclude transition-metal oxides into this category. Materials of this category often show good CDI capacities and cycling abilities.

\subsubsection{Sodium Manganese Oxide and Manganese Oxide}

Sodium manganese oxide (NMO) is an environmentally friendly, commonly studied Na-ion battery material with a low cost [76-78]. The voltage plateau is around $0.9 \mathrm{~V}$ vs. SHE (Standard Hydrogen Electrode) and the valence of $\mathrm{Mn}$ changes within the range of $+3-+4$. The theoretical electrochemical capacity of the material is over $100 \mathrm{mAh} \cdot \mathrm{g}^{-1}$, which determines the relatively large CDI capacities that are shown in the following studies.

As shown in Figure 2, Lee et al. (2014) [79] reported a flow-by CDI device with a $\mathrm{Na}_{4} \mathrm{Mn}_{9} \mathrm{O}_{18}$ anode and a porous carbon cathode and an anion-exchange membrane separating them. The cathode acted as a sodium acceptor so when the cathode was charged by a negative voltage, the sodium ions intercalated into the material and were released into the solution the other way around. The material revealed a salt removal capacity of $31.2 \mathrm{mg} \cdot \mathrm{g}^{-1}$, which was much higher than the traditional activated carbon electrode.

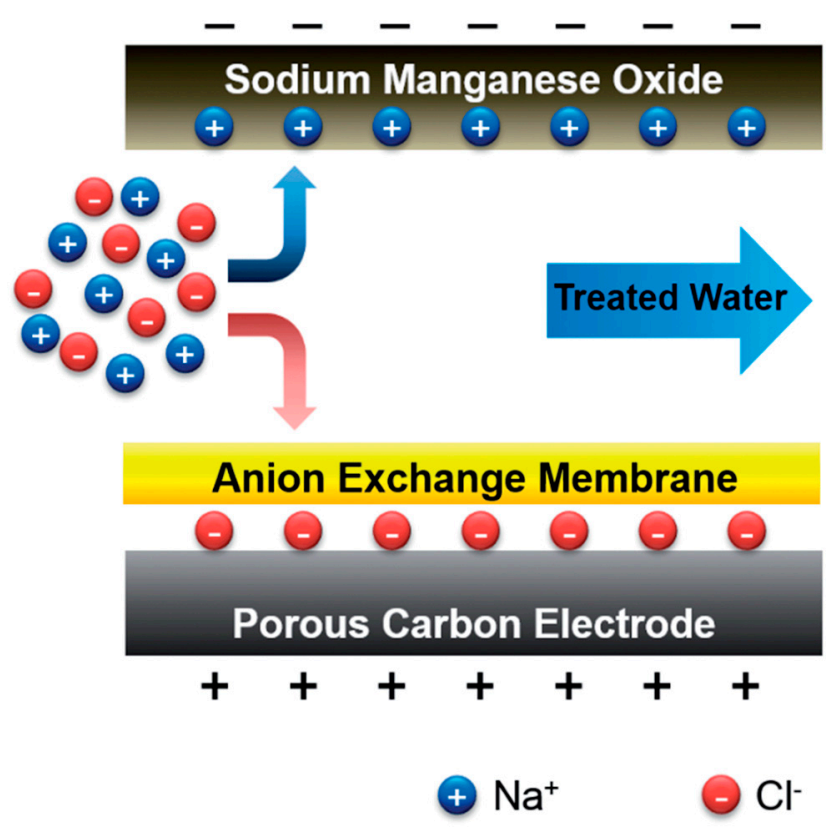

Figure 2. NMO\|AC HCDI (hybrid capacitive deionization) system with an anion-exchange membrane. Reproduced with permission from Ref. [75]. Copyright 2014 Royal Society of Chemistry. 
Chen et al. (2017) [80] constructed a CDI system with a $\mathrm{Na}_{0.44} \mathrm{MnO}_{2}$ electrode for the intercalation/deintercalation of sodium and a $\mathrm{AgCl}$ electrode for the intercalation/deintercalation of chloride (Figure 3). The $\mathrm{Na}_{0.44} \mathrm{MnO}_{2}$ acted as a sodium donor and cathode that could markedly decrease the polarization of the electrode, while the $\mathrm{AgCl}$ acted as the chloride donor and anode. The $\mathrm{Na}_{0.44} \mathrm{MnO}_{2}$ was obtained by a solid-state reaction. When the system was charged, sodium and chloride were released into the solution from the electrodes; when the system was discharged, sodium and chloride were captured by the electrodes, which showed a typical working mode of battery materials. The whole system represented a good cycling ability and a good salt removal capacity $\left(54.4 \mathrm{mg} \cdot \mathrm{g}^{-1} \mathrm{after} 100\right.$ cycles, calculated by the total mass of the electrodes).

(a)

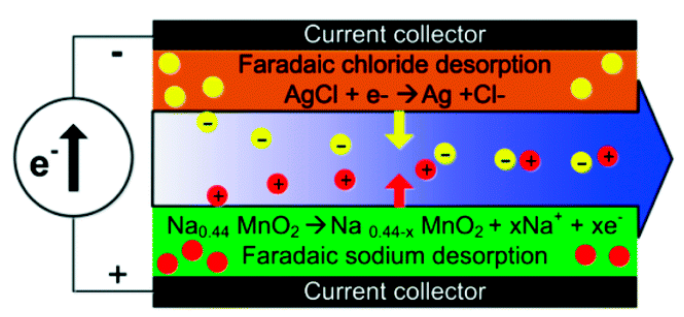

Salt desorption (b)

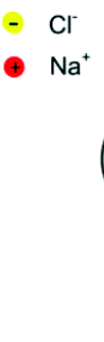

Salt absorption

Figure 3. Desalination (a) and regeneration (b) of NMO $\| \mathrm{AgCl} C D I$ system. Reproduced with permission from Ref. [76]. Copyright 2017 Royal Society of Chemistry.

One of the disadvantages of the oxide is that the conductivity is relatively low which could decrease the robustness of the material [81]. One solution to the problem is to incorporate the material with carbon [82]. Chen et al. (2016) [83] synthesized the $\mathrm{MnO}_{2} / \mathrm{MNCNT}$ composite that was used in the CDI process. The existence of carbon nanotubes dramatically improved the salt removal capacity by three times and the electrochemical capacitance by $50 \%$ and showed excellent recyclability because the carbon nanotubes promoted conductivity and specific surface area of the material.

Different morphological structures of the material could influence the performance of the salt removal performance. $\mathrm{MnO}_{2}$ materials that appeared in the literature could be grouped into $\alpha, \beta, \gamma$, $\delta, \lambda$ and amorphous phases. The $\alpha, \beta$ and $\gamma$ phases exhibited 1D structures and the $\delta$ and $\lambda$ phases exhibited 2D and 3D structures, respectively. Leong et al. (2019) [84] reported that the $\alpha-\mathrm{MnO}_{2}$ and $\delta-\mathrm{MnO}_{2}$ had higher deionization capacities than that of $\lambda-\mathrm{MnO}_{2}$ and the poorly crystalline $\mathrm{MnO}_{2}$ had better desalination performance than that of crystalline $\mathrm{MnO}_{2}$, which indicated that the desalination was due to both intercalation and surface adsorption. Xu et al. (2019) [85] synthesized a series of $\mathrm{MnO}_{2}$ materials of $\alpha, \beta, \gamma$ and $\delta$ phases and tested their CDI desalination performances, meaning that the order of deionization efficiency (from high to low) was: $\beta, \alpha, \gamma$ and $\delta$, because the surface ionization of hydrous $\mathrm{MnO}_{2}$ affected the deionization process.

\subsubsection{Sodium Cobalt Oxide and Cobalt Oxide}

Sodium cobalt oxide (NCO) is a Na-ion battery material with a relatively high theoretical electrochemical capacity (about $235 \mathrm{mAh} \cdot \mathrm{g}^{-1}$ ) that might lead to a good desalination performance and a cost that is not low because of the cobalt [86-88].

Liu et al. (2020) [89] synthesized $\mathrm{Na}_{0.71} \mathrm{CoO}_{2}$ from $\mathrm{Co}_{3} \mathrm{O}_{4}$ and $\mathrm{Na}_{2} \mathrm{CO}_{3}$ and then used it as the cathode in the flow-by CDI device with a $\mathrm{Ag} / \mathrm{rGO}$ anode and a cation-exchange membrane separating them. The salt removal capacity was up to about $29 \mathrm{mg} \cdot \mathrm{g}^{-1}$ in the first cycle but decreased by $34 \%$ after 50 cycles which might be due to the structural deterioration of NCO. Replacing the Co atoms with other atoms to make the structure more stable might be a good choice.

To stabilize the structure of $\mathrm{NCO}$ is the key point to get a good desalination performance. Zhou et al. (2019) [90] synthesized the $\mathrm{Na}_{0.27} \mathrm{Ca}_{0.03} \mathrm{CoO}_{2} \cdot 0.6 \mathrm{H}_{2} \mathrm{O}$ from $\mathrm{Co}\left(\mathrm{NO}_{3}\right)_{2}, \mathrm{Ca}\left(\mathrm{NO}_{3}\right)_{2}, \mathrm{NaNO}_{3}$ 
and citric acid. Compared to the undoped NCO, the new material got almost the same pair of oxidation/reduction peaks but a higher capacitance of $292 \mathrm{~F} \cdot \mathrm{g}^{-1}$. The doped material's salt removal capacity was $83.5 \mathrm{mg} \cdot \mathrm{g}^{-1}$ at $1.4 \mathrm{~V}$ in the first cycle which merely decreased after 50 cycles while the undoped material showed a desalination capacity of $58.4 \mathrm{mg} \cdot \mathrm{g}^{-1}$ in the first cycle which decreased to $39.5 \mathrm{mg} \cdot \mathrm{g}^{-1}$ after 12 cycles. The substitution of cobalt made the crystals larger and thinner, making it easy for sodium ions to diffuse.

\subsubsection{Sodium Titanium Oxide and Titanium Oxide}

Sodium titanium oxide (NTO) is an eco-friendly, hydrophilic Na-ion battery material with an appropriate voltage plateau and a high electrochemical capacity [91-93].

Moustafa et al. (2020) [94] reported that the $\mathrm{TiO}_{2}$-decorated $\mathrm{rGO}\left(\mathrm{TiO}_{2}\right.$ mass is $15 \%$ with respect to $\mathrm{rGO}$ ) showed a salt removal capacity of $24.576 \mathrm{mg} \cdot \mathrm{g}^{-1}$ at $1.2 \mathrm{~V}$ while the $\mathrm{rGO}$ showed a capacity of $13.58 \mathrm{mg} \cdot \mathrm{g}^{-1}$. The composite also exhibited an ultrahigh electrochemical capacitance of $635.1 \mathrm{~F} \cdot \mathrm{g}^{-1}$, much higher than the rGO's capacitance $\left(87.77 \mathrm{~F} \cdot \mathrm{g}^{-1}\right)$. The reasons for the promoted performances might be the improvement of the wettability and the surface area of the material.

Yue et al. (2019) [95] synthesized $\mathrm{C} / \mathrm{Na}_{4} \mathrm{Ti}_{9} \mathrm{O}_{20}$ nanotubes with a hydrothermal method with the use of $\mathrm{NaOH}$. The material exhibited an extraordinary desalination capacity of $80.56 \mathrm{mg} \cdot \mathrm{g}^{-1}$ at $1.4 \mathrm{~V}$ and a charge efficiency near $100 \%$. The electrochemical capacitance of the material was $153.34 \mathrm{~F} \cdot \mathrm{g}^{-1}$ and remained $92.42 \%$ after 100 constant voltage $(\mathrm{CV})$ cycles, much higher than the pure NTO's capacitance $\left(62.84 \mathrm{~F} \cdot \mathrm{g}^{-1}\right)$. After the coating of carbon, the charge transfer resistance decreased to 0.98 from $2.26 \Omega$ according to the EIS experiment and the contact angle decreased to $34^{\circ}$ from $68^{\circ}$, indicating a more convenient ion transportation. The material had a carbon-incorporated core-shell structure, contributing to the enhancement of not only the conductivity but also the stability and electrochemical performance.

\subsubsection{Tin Oxide}

$\mathrm{SnO}_{2}$ is a promising green Na-ion battery anode material with a particularly high theoretical electrochemical capacity of about $1500 \mathrm{mAh} \cdot \mathrm{g}^{-1}$ but little of the capacity is inside the voltage window of water [96-98]. Besides, $\mathrm{SnO}_{2}$ has a low conductivity and its volume changes rapidly during the charge/discharge process which could undermine the material's structure [99], so it is worth considering integrating the material with carbon during the CDI process.

The graphene is a layered material that could provide an approach for nanoparticles to be stabilized onto the sheets. A graphene/ $\mathrm{SnO}_{2}$ composite was synthesized with a microwave method by El-Deen et al. (2014) [100] and was then tested in the CDI process. The material $\left(\mathrm{SnO}_{2} 15 \mathrm{wt} \%\right)$ exhibited a salt removal of $1.49 \mathrm{mg} \cdot \mathrm{g}^{-1}$ at $1.4 \mathrm{~V}$, twice as much as that of graphene. According to the CV experiment, the electrochemical capacitance of the graphene $/ \mathrm{SnO}_{2}$ material was $323 \mathrm{~F} \cdot \mathrm{g}^{-1}$. The intercalation of the $\mathrm{SnO}_{2}$ nanoparticles obviously changed the electrochemical behavior and enlarged the space between graphene sheets thus increasing the material's surface area.

Generally, doping enhances the performance of materials. Yasin et al. (2017) [101] synthesized a $\mathrm{N}$-doped $\mathrm{AC} / \mathrm{SnO}_{2}$ composite with a hydrothermal method using urea as the source of nitrogen. With the doping of $\mathrm{N}$, the material's salt removal capacity increased by $56.2 \%$ to $3.42 \mathrm{mg}^{-1} \mathrm{~g}^{-1}$. Its specific capacitance increased by $75.3 \%$ to $408.8 \mathrm{~F} \cdot \mathrm{g}^{-1}$. The doping of nitrogen increased the defects and wettability of the material, leading to the progresses mentioned above.

\subsubsection{Zinc Oxide}

$\mathrm{ZnO}$ is a sodium ion battery anode material with low cost, high electrochemical capacity and easy accessibility [102-104]. There have been some efforts made by scientists exploring the feasibility of utilizing $\mathrm{ZnO}$ in the CDI system.

Liu et al. (2015) [105] constructed two hybrid capacitive deionization (HCDI) systems with $\mathrm{ZnO}$ electrodes and activated carbon electrodes, one with an AC-coated anode (-ZnO/AC\|AC) and the other 
with an AC-coated $\mathrm{ZnO}$ cathode $(+\mathrm{ZnO} / \mathrm{AC} \| \mathrm{AC})$. The $\mathrm{CDI}$ experiments were conducted in $500 \mathrm{ppm}$ $\mathrm{NaCl}$ solution at the voltage of $1.2 \mathrm{~V}$. The $\mathrm{CV}$ curve of $\mathrm{ZnO} / \mathrm{AC}$ was a rectangular shape, indicating an electrical double layer behavior and a capacitance of $66 \mathrm{~F} \cdot \mathrm{g}^{-1}, 33.6 \%$ higher than that of the AC electrode, which was due to the enhanced wettability. $\mathrm{ZnO} / \mathrm{AC}$ also showed a lower charge transfer resistance that was beneficial to better CDI performance. The $-\mathrm{ZnO} / \mathrm{AC} \| \mathrm{AC}$ system exhibited a salt removal capacity of $9.4 \mathrm{mg} \cdot \mathrm{g}^{-1}$ after 12 cycles, which was twice of that of $+\mathrm{ZnO} / \mathrm{AC} \| \mathrm{AC}$ system and $\mathrm{AC} \| \mathrm{AC}$ system. The $\mathrm{ZnO}$ gradually deteriorated in the electrolyte, leading to an unstable and low deionization performance.

Arora et al. (2019) [106] synthesized graphene/CNT/ZnO (FGC-ZnO) composite and constructed a symmetric CDI system using the material as the electrodes. The FGC-ZnO with a $\mathrm{ZnO}$ content of $10 \%$ exhibited a specific capacitance of $280 \mathrm{~F} \cdot \mathrm{g}^{-1}$ and a desalination capacity of $28.62 \mathrm{mg} \cdot \mathrm{g}^{-1}$, which were $33 \%$ and $15 \%$ higher than those of graphene/CNT composite due to the faster ion diffusion on the surface of the material detected by impedance spectra of EIS experiments.

\subsubsection{Iron Oxide}

Iron oxide is an ideal anode material for sodium-ion batteries owing to the convenient cost, eco-friendliness, chemical stability and high capacity [107-109]. The iron oxide that appeared in the literature of CDI research was $\mathrm{Fe}_{3} \mathrm{O}_{4}$, which has not only a theoretical capacity of $926 \mathrm{mAh} \cdot \mathrm{g}^{-1}$ but also a conductivity much higher than $\mathrm{Fe}_{2} \mathrm{O}_{3}$.

A rGO/ $\mathrm{Fe}_{3} \mathrm{O}_{4}$ material was prepared by Li et al. (2016) [110] with a hydrothermal method and employed as both electrodes in the $\mathrm{CDI}$ system. $\mathrm{Fe}_{3} \mathrm{O}_{4}$ nanoparticles were uniformly coated with $\mathrm{rGO}$ sheets, which was good for charge and ion diffusion. The hydroxylation reaction occurred on the surface of $\mathrm{Fe}_{3} \mathrm{O}_{4}$ which provided a higher electrochemical capacity and a larger desalination capacity of $\mathrm{rGO} / \mathrm{Fe}_{3} \mathrm{O}_{4}$ compared to those of pure rGO. The CDI experiments showed that the desalination capacity of the former was twice of that of the latter. According to the Langmiur isotherm prediction, the maximum deionization capacity of $\mathrm{rGO} / \mathrm{Fe}_{3} \mathrm{O}_{4}$ was $8.33 \mathrm{mg} \cdot \mathrm{g}^{-1}$.

Trinh et al. (2016) [111] synthesized $\mathrm{Fe}_{3} \mathrm{O}_{4} / \mathrm{rGO}$ composite by a facile thermal hydrolysis process. The $\mathrm{Fe}_{3} \mathrm{O}_{4}$ nanoparticles distributed uniformly around the graphene oxide sheets. The composite with the mean size of the particles of $25 \mathrm{~nm}$ exhibited a desalination capacity of $4.3 \mathrm{mg} \cdot \mathrm{g}^{-1}$ at $1.5 \mathrm{~V}$, that was 3.3 times of that of pure $\mathrm{rGO}$, which could be attributed to the larger surface area and lower ion diffusion resistance provided by the $\mathrm{Fe}_{3} \mathrm{O}_{4}$ nanoparticles.

\subsubsection{Binary Transition Metal Oxide}

Binary transition metal oxide has become a hotspot of battery materials research due to its ability to combine advantages of different materials together.

$\mathrm{NiCO}_{2} \mathrm{O}_{4}$ is not only a Na-ion battery material but also an electrode material that appeared in the research literature of aqueous batteries and supercapacitors [112-114]. It has advantages of high specific capacitance (up to $1400 \mathrm{~F} \cdot \mathrm{g}^{-1}$ ) [115] and high conductivity. Liu et al. (2020) [116] synthesized echinus-like $\mathrm{NiCO}_{2} \mathrm{O}_{4}$ nanocrystals with a solvothermal method which exhibited a specific capacitance of $184.8 \mathrm{~F} \cdot \mathrm{g}^{-1}$ in the $1 \mathrm{M} \mathrm{NaCl}$ solution and a high CDI capacitance of $44.3 \mathrm{mg} \cdot \mathrm{g}^{-1}$ at $1.2 \mathrm{~V}$.

$\mathrm{MnFe}_{2} \mathrm{O}_{4}$ is a material mostly used in Na-ion batteries and supercapacitors [117-119]. This material has a very stable structure that the lattice expansion of which is very little during the charge/discharge process [120]. Younes et al. (2020) [121] synthesized $\mathrm{MnFe}_{2} \mathrm{O}_{4} / \mathrm{rGO}$ composite with a hydrothermal method and the material showed a salt adsorption capacity of $38.28 \mathrm{mg} \cdot \mathrm{g}^{-1}$ in a pseudocapacitive deionization system with $\mathrm{MnO}_{2} / \mathrm{rGO}$ as the other electrode.

\subsection{NASICON Material}

NASICONs stand for sodium super ion conductors [122,123]. NASICON materials are a type of materials that have certain advantages such as: i. wide spaces between unit cells as active sites for sodium storage; ii. tunnels in the 3D-frameworks that allow the easy transportation of sodium ions; 
iii. weak interactions between structure frameworks and sodium ions that are good for the diffusion of the ions. NASICON materials have been widely studied for Na-ion battery research.

\subsection{1. $\mathrm{NaTi}_{2}(\mathrm{PO} 4)_{3}$}

$\mathrm{NaTi}_{2}(\mathrm{PO} 4)_{3}$ is one of the few appropriate aqueous sodium-ion battery anode materials that have been studied in the literature $[124,125]$. NTP is an environmentally friendly battery material with a high capacity of $133 \mathrm{mAh} \cdot \mathrm{g}^{-1}$ and a suitable voltage plateau (about $-0.6 \mathrm{~V}$ vs. SHE) just inside the voltage window of water [126,127].

Huang et al. (2017) [128] synthesized the $\mathrm{NaTi}_{2}(\mathrm{PO} 4)_{3} / \mathrm{rGO}$ nanocomposite by a solvothermal reaction, which exhibited better desalination capacities and cycling abilities than pure NTP. The deionization capacities were tested in a HCDI system with the nanocomposite as the anode covered by a cation-exchange membrane and the activated carbon as the cathode covered by an anion-exchange membrane under the constant current mode (Figure 4). The composite showed a salt adsorption capacity of $140 \mathrm{mg} \cdot \mathrm{g}^{-1}$ and retained $120 \mathrm{mg} \cdot \mathrm{g}^{-1}$ after 100 cycles while the pure NTP showed a capacity of $112 \mathrm{mg} \cdot \mathrm{g}^{-1}$ and retained $71 \mathrm{mg} \cdot \mathrm{g}^{-1}$ after 100 cycles. The $\mathrm{rGO}$ enhanced the material's ion and electron conductivity.

(a)

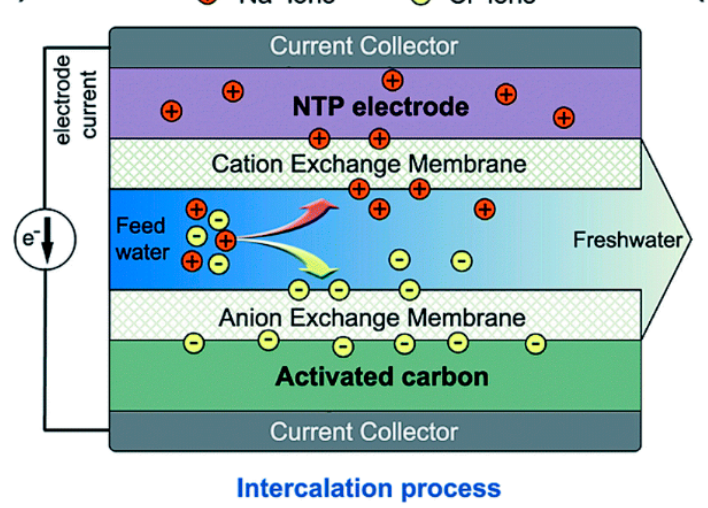

(b)

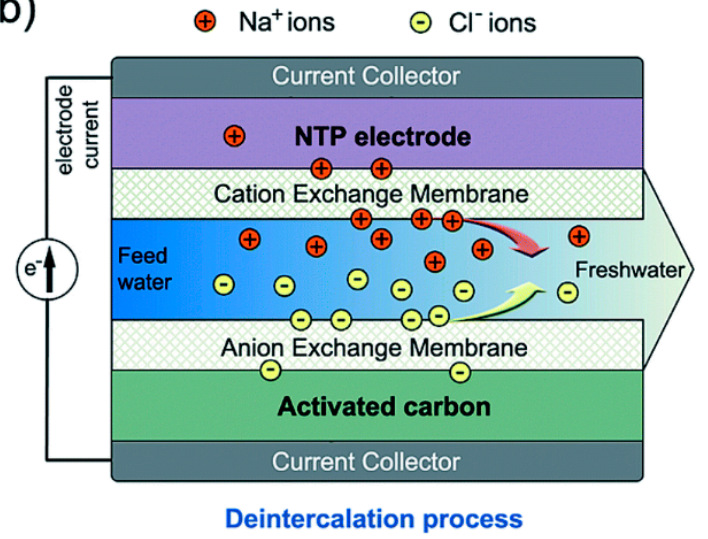

Figure 4. Desalination (a) and regeneration (b) of NTP\|AC HCDI system with ion-exchange membranes. Reproduced with permission from Ref. [124]. Copyright 2017 Royal Society of Chemistry.

Nonmetallic heteroatom doping is a feasible way to enhance the carbonaceous material's conductivity and electrochemical performance [129,130]. Liang et al. (2020) [131] used a one-step hydrothermal reaction to synthesize N-S co-doped NTP/hole graphene composite with $\mathrm{H}_{2} \mathrm{O}_{2}$ as the hole etchant and thiourea as the source of $\mathrm{N}$ and $\mathrm{S}$. The doped composite showed a salt removal capacity of $36.87 \mathrm{mg} \cdot \mathrm{g}^{-1}$ at $1.4 \mathrm{~V}$ in the $800 \mathrm{ppm} \mathrm{NaCl}$ solution while the undoped showed a capacity of $33.25 \mathrm{mg} \cdot \mathrm{g}^{-1}$ under the same condition. The doped composite also exhibited a specific capacitance of $530.5 \mathrm{~F} \cdot \mathrm{g}^{-1}, 33.8 \%$ higher than the undoped material. The doping of $\mathrm{N}$ and $\mathrm{S}$ reduced the ion diffusion resistance, modified the surface of the material and offered more active sites.

Since the NTP material has such a high capacity of salt removal, the combination of this material with a Ag cathode of high capacity for chloride ion intercalation to form a CDI system could be an energy-efficient choice. Huang et al. (2019) [132] constructed a CDI system with a $\mathrm{NaTi}_{2}\left(\mathrm{PO}_{4}\right)_{3} / \mathrm{rGO}$ anode and a Ag/rGO cathode and recorded a salt removal capacity of $105 \mathrm{mg} \cdot \mathrm{g}^{-1} \mathrm{during} 50$ cycles. The energy consumption of the system turning the salinity of the water from 2500 to 500 ppm is just $0.254 \mathrm{Wh} \cdot \mathrm{g}^{-1}$, that was competitive compared to the reverse osmosis technology. Wang et al. (2018) [133] integrated the desalination process with the energy storage process by constructing an aqueous battery consisting of a NTP anode, a Ag cathode and $\mathrm{NaCl}$ solution as the electrolyte. The system was charged by a solar cell and exhibited a desalination capacity of $\sim 151.5 \mathrm{mg} \cdot \mathrm{g}^{-1}$ and no obvious capacity decay was observed after 50 cycles. The battery's capacity remained $50 \mathrm{mAh} \cdot \mathrm{g}^{-1}$ 
after 1500 cycles at the current density of $10 \mathrm{C}$, which was $70 \%$ of the original capacity. The battery operated with an output voltage of $0.84 \mathrm{~V}$, indicating a good potential of the device.

\subsection{2. $\mathrm{Na}_{3} \mathrm{~V}_{2}\left(\mathrm{PO}_{4}\right)_{3}$}

NVP is an aqueous Na-ion battery cathode material with a high capacity and the redox of $\mathrm{V}^{4+} / \mathrm{V}^{3+}$ allows the intercalation of sodium, the process of which is energy-saving [134-136].

Cao et al. (2019) [137] prepared NVP/C material with a sol-gel method with citric acid as the source of carbon and then used it in the CDI testing. The flow-by CDI system consisted of a NVP/C cathode, an activated carbon anode, and an anion-exchange membrane separating them. The NVP/C material showed an ultrahigh salt removal capacity of $137.2 \mathrm{mg} \cdot \mathrm{g}^{-1}$ at the voltage of $1 \mathrm{~V}$ with the energy consumption of $2.16 \mathrm{~g}-\mathrm{NaCl} \cdot \mathrm{Wh}^{-1}$, which was more efficient compared to the carbon electrodes.

The binders are always used in electrochemical experiments, but they could also block active sites and decrease the conductivities of the materials [138], thus impairing the electrochemical and deionization performances. To explore an approach to solving the issue, Zhao et al. (2019) [139] synthesized $\mathrm{NVP} /$ graphene and $\mathrm{AgCl} /$ graphene aerogels with a solvothermal method and a hydrothermal method, respectively, and employed them directly as electrodes in a CDI system with ion-exchange membranes covering each of them. The salt removal capacity of the binder-free CDI system was $107.5 \mathrm{mg} \cdot \mathrm{g}^{-1}$, much better than the capacity of the one with binders $\left(67.08 \mathrm{mg} \cdot \mathrm{g}^{-1}\right.$ at the same current density of $\left.0.1 \mathrm{~A} \cdot \mathrm{g}^{-1}\right)$. In contrast with the ones with binders retaining $72.86 \%$ of the capacity after 50 cycles, the binder-free electrodes retained $88.69 \%$ of the capacity, indicating a better cycling ability.

\subsection{3. $\mathrm{Na}_{2} \mathrm{FeP}_{2} \mathrm{O}_{7}$}

Sodium iron pyrophosphate is a material suitable for aqueous sodium-ion battery cathode for its good capacity (about $90 \mathrm{mAh} \cdot \mathrm{g}^{-1}$ ), appropriate voltage plateau (+0.3 V vs. SHE), well-defined tunnel structures for facile ion transportation and eco-friendliness and low cost [140].

Kim et al. (2016) [141] reported a CDI system with the $\mathrm{Na}_{2} \mathrm{FeP}_{2} \mathrm{O}_{7} / \mathrm{C}$ material prepared by a solid-state reaction as the sodium intercalation electrode and an activated carbon electrode coated by an anion-exchange membrane. Before the $\mathrm{CDI}$ experiment, the $\mathrm{Na}_{2} \mathrm{FeP}_{2} \mathrm{O}_{7}$ electrode was charged to release the sodium ions to make sodium intercalation sites available. During the CDI test, the sodium ions were captured when the $\mathrm{Na}_{2} \mathrm{FeP}_{2} \mathrm{O}_{7}$ electrode was charged by a negative voltage, and the chloride ions were captured by the activated carbon electrode. The material exhibited a salt removal capacity of $30.2 \mathrm{mg} \cdot \mathrm{g}^{-1}$ and a specific capacity of $56 \mathrm{mAh} \cdot \mathrm{h}^{-1}$ at the current density of $48 \mathrm{~mA} \cdot \mathrm{g}^{-1}$ with the galvanostatic method, much higher than the traditional carbon electrodes.

\subsection{Prussian Blue Analogue}

Prussian blue analogues (PBAs) are a class of materials that can be represented as $\mathrm{A}_{x} \mathrm{M}\left[\mathrm{Fe}(\mathrm{CN})_{6}\right]$. The " $\mathrm{A}$ " stands for alkali metal cation and " $\mathrm{M}$ " stands for transition metal ion [142,143]. The intercalation of sodium is mainly related to the valence change of the transition metal ions in the framework $[144,145]$. This kind of materials usually have two features closely related to energy storage: i. wide tunnels in the 3D structure that have weak interaction with ions, in favor of transportation of ions; ii. the vacancies of $\left[\mathrm{Fe}(\mathrm{CN})_{6}\right]$ could be reduced by controlling the synthesis process of the material, which is essential to the long cycle life and high capacity.

As summarized in Figure 5, Lee et al. (2017) [146] used a symmetric Na-ion desalination (NID) system to remove the salt ions in brackish water. The system consisted of two sodium intercalation electrodes and an anion-exchange membrane between them blocking the movement of cations and allowing the chloride ions to pass through. The brackish water would be divided into diluted solution and concentrated solution at the same time during the charge/discharge process. Compared to the HCDI system, the symmetric system could reduce the polarization of the electrodes. The NaNiHCF and $\mathrm{NaFeHCF}$ materials were synthesized via a controlled crystallization reaction and employed as the 
sodium intercalation electrodes. The system exhibited a good salt removal capacity of $59.9 \mathrm{mg} \cdot \mathrm{g}^{-1}$ and a low energy consumption of $0.34 \mathrm{Wh} \cdot \mathrm{g}^{-1}$ for seawater desalination with a $40 \%$ salt removal efficiency.
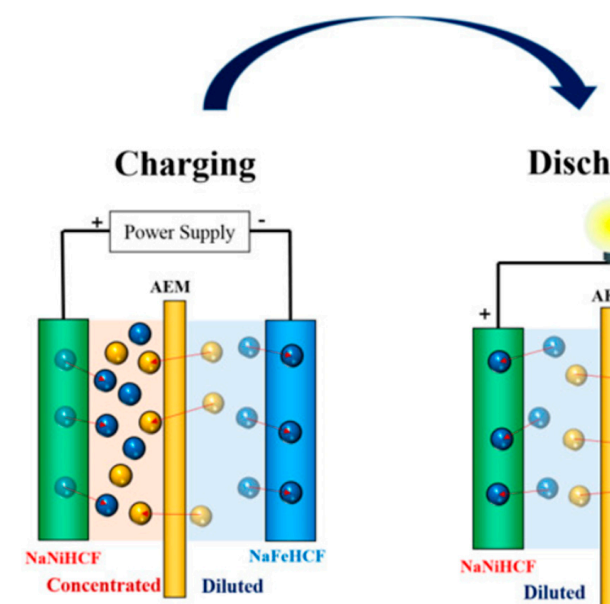

\section{Discharging}
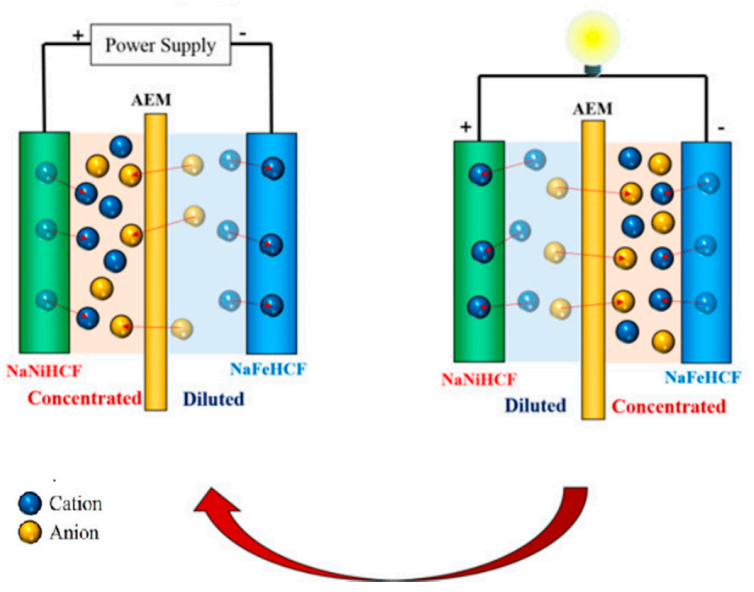

Figure 5. Desalination (charge) process and regeneration (discharge) process of Na-ion desalination (NID) system with NaNiHCF and NaFeHCF electrodes. Reproduced with permission from Ref. [142]. Copyright 2017 American Chemical Society.

Porada et al. (2017) [147] reported a flow-through CDI device that consisted of two sodium intercalation electrodes and an anion-exchange membrane in direct contact with and separating each of them (Figure 6). The solution in the system was divided by the electrodes into two channels and only anions were allowed to move between them. When the current went through, the sodium ions were released and absorbed by the corresponding electrode, thus forming the diluted solution and concentrated solution on the different sides. The distance between the electrodes was rapidly reduced, which was beneficial for good desalination performance. The sodium-rich form of NiHCF was synthesized by a solution/precipitation reaction while the sodium-deficient form was prepared by electrochemical oxidation of the former, both of which were employed as CDI electrodes. The salt adsorption capacity exhibited was $34 \mathrm{mg} \cdot \mathrm{g}^{-1}, 2.5$ times the capacity of the carbon.

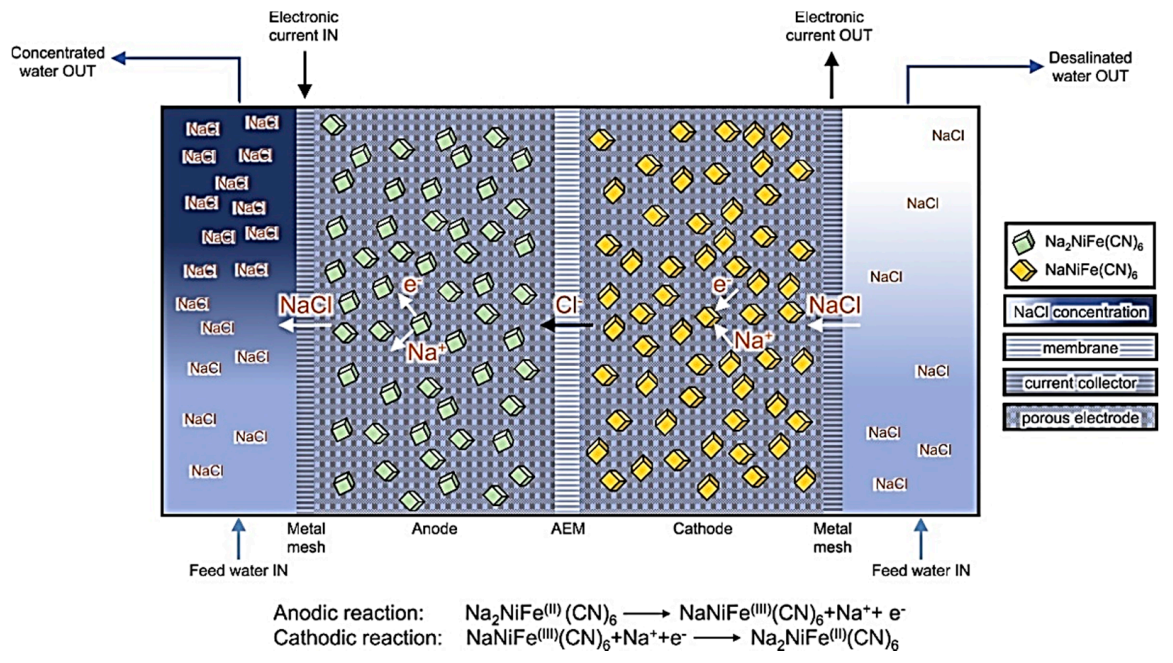

Figure 6. NID system with sodium-rich and sodium-deficit NiHCF electrodes. Reproduced with permission from Ref. [143]. Copyright 2017 Elsevier. 
$\mathrm{FeFe}(\mathrm{CN})_{6}$ is an aqueous sodium-ion battery electrode material with a high theoretical capacity of $180 \mathrm{mAh} \cdot \mathrm{g}^{-1}$ and good rate performance [148]. Guo et al. (2017) [66] synthesized $\mathrm{FeFe}(\mathrm{CN})_{6}$ nanocubes with a precipitation method, graphene oxide with nanopores (NPG) were synthesized by a hydrothermal reaction with the $\mathrm{H}_{2} \mathrm{O}_{2}$ as the etchant, and $\mathrm{FeFe}(\mathrm{CN})_{6} / \mathrm{NPG}$ composite with a precipitation reaction followed by freeze-drying. The composite exhibited an extraordinary salt removal capacity of $120 \mathrm{mg} \cdot \mathrm{g}^{-1}$ at $1 \mathrm{C}$ via the constant current mode in the HCDI system with carbon as the counter-electrode. The salt removal capacity of $\mathrm{FeFe}(\mathrm{CN})_{6} / \mathrm{NPG}$ barely decreased after 100 cycles at $4 \mathrm{C}$, while the capacity of $\mathrm{FeFe}(\mathrm{CN})_{6}$ declined much faster. The NGP promoted the electric and ionic conductivity of the material and prevented the electrochemical capacity from deteriorating by preventing the nanocubes from being flushed away.

\subsection{Iron Phosphate}

$\mathrm{FePO}_{4}$ is known as a precursor material widely used for the production of lithium-ion battery materials [149] as well as sodium ion batteries [150,151], whose oxidation/reduction reaction of $\mathrm{Fe}^{3+} / \mathrm{Fe}^{2+}$ allows the intercalation and deintercalation of sodium ions. The $\mathrm{FePO}_{4}$ material has advantages of low cost, high chemical stability, eco-friendliness, appropriate voltage plateau in the aqueous environment, high theoretical capacity of about $178 \mathrm{mAh} \cdot \mathrm{g}^{-1}$ but also suffers the disadvantages of low conductivity and ion diffusion coefficient [152]. Incorporating $\mathrm{FePO}_{4}$ with carbon materials could be an applicable approach to improving the electrochemical performances of the material.

$\mathrm{FePO}_{4}$ has an amorphous phase and many crystalline phases including heterosite, $\alpha$ - quartz, monoclinic and orthorhombic phases. Guo et al. (2018) [153] prepared $\mathrm{FePO}_{4} / \mathrm{rGO}$ composite using the amorphous $\mathrm{FePO}_{4}$ due to the synthesis simplicity and abundance in nature, and the composite was used as the anode in a HCDI system with activated carbon as the cathode. The salt removal capacity of $\mathrm{FePO}_{4} / \mathrm{rGO}$ was $100 \mathrm{mg} \cdot \mathrm{g}^{-1}$ after 50 cycles without declining while the capacity of the pure $\mathrm{FePO}_{4}$ decreased to 64 from $84.8 \mathrm{mg} \cdot \mathrm{g}^{-1}$. The graphene network enhanced the conductivity and prevented the $\mathrm{FePO}_{4}$ particles from aggregation.

Ma et al. (2019) [154] used a facile one-step hydrothermal method to synthesize $\mathrm{FePO}_{4} / \mathrm{rGO}$, which was then employed as HCDI electrode. The graphene sheets provided ideal platforms for the growth of $\mathrm{FePO}_{4}$ nanospheres, which in turn prevented the stack of the graphene. This further enhanced the interaction of the electrodes and the brackish water. $\mathrm{FePO}_{4} / \mathrm{rGO}$ showed a desalination capacity of $85.94 \mathrm{mg} \cdot \mathrm{g}^{-1}, 71.4 \%$ higher than that of $\mathrm{FePO}_{4}$. To adsorb $1 \mathrm{~g} \mathrm{NaCl}$ from brackish water, the gross cost of raw materials was less than one dollar, and the energy consumption was $0.9 \mathrm{Wh} \cdot \mathrm{g}^{-1}$, both of which were economically competitive.

\subsection{Molybdenum Disulfide}

$\mathrm{MoS}_{2}$ is a two-dimensional layered sodium battery anode material with a great potential due to the high theoretical capacity $\left(669 \mathrm{mAh} \cdot \mathrm{g}^{-1}\right)$, low cost and abundant reserves $[155,156]$. Though the major capacity of the material is outside the voltage window of water, the layered structure still allows the intercalation of aqueous ions which indicate the CDI potential.

Unlike PBA materials in the sodium intercalation process, the $\mathrm{MoS}_{2}$ provides sites for intercalation of both cations and anions. Srimuk et al. (2017) [157] synthesized $\mathrm{MoS}_{2} / \mathrm{CNT}$ composite with a sonication method, which was employed as both electrodes in the CDI system without membranes. The CNTs enhanced not only the conductivity but also the mechanical stability of the material. Before being tested in the CDI system, the composite was activated in an electrochemical way by charging the material with $+10 \mathrm{~V}$ in the aqueous three-electrode system for $4 \mathrm{~h}$, thus expanding the layering by the accumulation of the $\mathrm{O}_{2}$ and $\mathrm{SO}_{2}$ gases within the material decomposed of hydroxyl and sulfide ions. The salt removal capacity of the activated material was $10 \mathrm{mg} \cdot \mathrm{g}^{-1}$ in a $5 \mathrm{mM} \mathrm{NaCl}$ solution, 17 times of that of the unactivated material, indicating the key role of the activation. The $\mathrm{MoS}_{2} / \mathrm{CNT}$ composite could exhibit a higher and stable desalination capacity of $25 \mathrm{mg} \cdot \mathrm{g}^{-1}$ in a $500 \mathrm{mM}$ solution. 
Modulating the surface of the material could be a practical approach to improving the deionization performances. Feifei et al. (2018) [158] prepared defect-rich $\mathrm{MoS}_{2}$ with a facile method which was employed as both electrodes of the CDI system. The defect-rich material showed a salt removal capacity of $35 \mathrm{mg} \cdot \mathrm{g}^{-1}$, nearly three times of that of $\mathrm{MoS}_{2}$ due to the additional negative charges and a low charge transfer resistance. Wang et al. (2019) [159] improved the wettability of $\mathrm{MoS}_{2}$ by incorporating hydrophilic polydopamine (PDA), thus forming $\mathrm{MoS}_{2} / \mathrm{PDA}$ composite. The $\mathrm{MoS}_{2} / \mathrm{PDA}$ material exhibited a salt removal capacity of $16.94 \mathrm{mg} \cdot \mathrm{g}^{-1}$ during 10 successive cycles, nearly $60 \%$ higher than that of pure $\mathrm{MoS}_{2}$, owing to the better conductivity, additional negative surface charges and lower inner resistance due to better wettability that PDA provided.

\subsection{Mxene}

Mxene is the generic name of a series of two-dimensional-layered materials including the carbides and nitrides of transition-metals and the complex of the two, which could be represented as $M_{n+1} X_{n} T_{x}$. The " $\mathrm{M}$ " stands for transition-metal element, " $\mathrm{X}$ " stands for carbon or nitrogen and " $\mathrm{T}$ " stands for the functional group [160]. Mxene is prepared from the MAX material (a three-element carbide or nitride), which has not only high electron and heat conductivity similar to metal but also extraordinary mechanical property, oxidation and erosion resistance similar to ceramics. Mxene has been widely studied as a sodium- and lithium-ion battery material due to its high capacity and effective cycling performance, and the good hydrophilicity of the material is also a noticeable profitable factor in the CDI experiments [161,162].

Wang et al. (2018) [163] modified the surface of $\mathrm{Ti}_{3} \mathrm{C}_{2} \mathrm{Tx}$ with an Ar plasma method. After $\mathrm{Ti}_{3} \mathrm{C}_{2} \mathrm{~T}_{\mathrm{x}}$ was prepared by a wet chemical process from $\mathrm{Ti}_{3} \mathrm{AlC}_{2}$, the Ar plasma modification was used to excite the residual water and $\mathrm{O}_{2}$ molecules to O-related radicals, thus replacing the former F-related groups inside the $\mathrm{Ti}_{3} \mathrm{C}_{2} \mathrm{~T}_{\mathrm{x}}$ sheets. The replacement of the groups not only enhanced the hydrophilicity of the material thus reducing the inner resistance of the transportation of ions, but also enlarged the interlayer distance, leading to a larger surface area and more intercalation sites for ions. The Ar-modified $\mathrm{Ti}_{3} \mathrm{C}_{2} \mathrm{~T}_{\mathrm{x}}$ showed a salt removal capacity of $26.8 \mathrm{mg} \cdot \mathrm{g}^{-1}$, nearly three times of that of the unmodified material.

Bao et al. (2018) [164] used a freeze-drying method to modify the structure of $\mathrm{Ti}_{3} \mathrm{C}_{2} \mathrm{~T}_{\mathrm{x}}$. The solidification and expansion of water in the material contributed to the larger interlayer distance, porous structure (Figure 7) and better hydrophilicity, thus enhancing the accessibility of the surface pores for the ions, leading to a better specific capacitance and desalination performance. During the CDI experiment, the porous $\mathrm{Ti}_{3} \mathrm{C}_{2} \mathrm{~T}_{\mathrm{x}}$ exhibited a salt removal capacity of $45 \mathrm{mg} \cdot \mathrm{g}^{-1}, 12.8$ times of that of the non-modified material, and cycled 60 times without capacity decay.
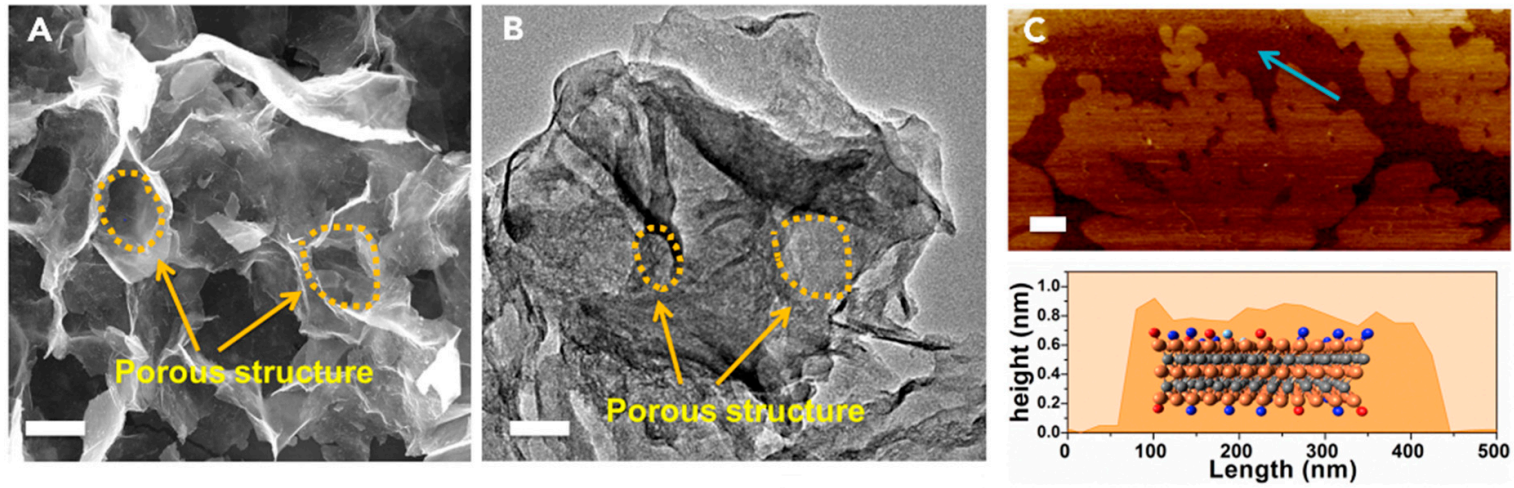

Figure 7. FESEM (A), HRTEM (B), and AFM (C) images of porous $\mathrm{Ti}_{3} \mathrm{C}_{2} \mathrm{~T}_{\mathrm{x}}$ structure. Reproduced with permission from Ref. [160]. Copyright 2018 Elsevier. 


\subsection{Ammonium Vanadate}

$\mathrm{NH}_{4} \mathrm{~V}_{4} \mathrm{O}_{10}$ is a newly developed CDI material that has been utilized as the cathode material in a sodium-ion battery due to its layered structure and stable framework [64].

$\mathrm{NH}_{4} \mathrm{~V}_{4} \mathrm{O}_{10} / \mathrm{rGO}$ composite was prepared by Li et al. (2020) [165] with a hydrothermal method from oxalic acid and $\mathrm{NH}_{4} \mathrm{VO}_{3}$, and was used as the cathode in the $\mathrm{CDI}$ system with activated carbon as the counter electrode. The sodium ions were intercalated and deintercalated in the lattices of V-O during the desalination and regeneration process, the interlayer space of which was about $1 \mathrm{~nm}$. Compared to pure $\mathrm{NH}_{4} \mathrm{~V}_{4} \mathrm{O}_{10}, \mathrm{NH}_{4} \mathrm{~V}_{4} \mathrm{O}_{10} / \mathrm{rGO}$ showed a larger surface area, a lower charge transfer impedance and a larger specific capacitance in the three-electrode experiment. $\mathrm{NH}_{4} \mathrm{~V}_{4} \mathrm{O}_{10} / \mathrm{rGO}$ exhibited a high salt removal capacity of $20.1 \mathrm{mg} \cdot \mathrm{g}^{-1}$ at $1.2 \mathrm{~V}$ in $500 \mathrm{ppm} \mathrm{NaCl}$ solution and remained $71.5 \%$ after 100 cycles due to the leaching of $\mathrm{V}$ and the charge efficiency declined with the increase in the voltage because of the side reactions.

\section{Li-Ion Battery Materials}

Various lithium battery materials have already been produced in a large scale and applied in daily life, including lithium manganese oxide [166,167], lithium cobalt oxide [168,169], ternary cathode material [170], lithium iron phosphate [171,172], etc. However, few of them have been reported in the literature employed as CDI electrodes mainly because the voltage plateaus might not exist within the voltage window of water.

\subsection{Lithium Titanium Oxide}

An attempt has been made by Guo et al. (2019) [173] using carbon-coated $\mathrm{Li}_{4} \mathrm{Ti}_{5} \mathrm{O}_{12}$ (LTO) synthesized with a solvothermal method as the anode in CDI testing under constant voltage and constant current modes. A cyclic voltammetry experiment of as-prepared LTO/C material was conducted using a three-electrode system with $1 \mathrm{M} \mathrm{NaCl}$ solution as the electrolyte, exhibiting an obvious oxidation/reduction reaction behavior and a specific capacitance of $95 \mathrm{~F} \cdot \mathrm{g}^{-1}$, indicating the sodium ion intercalation and deintercalation behavior occurred inside the material that lithium ions were replaced by sodium ions. The desalination capacity, charge efficiency and energy consumption of the constant current mode were better than those of constant voltage mode. LTO/C showed a desalination capacity of $25 \mathrm{mg} \cdot \mathrm{g}^{-1}$ which remained stable over 30 cycles under the mode of constant current, $25 \%$ higher than that of pure LTO. CDI experiments of LTO materials have revealed a great potential for real application because the production of the material is already available.

\subsection{Polyoxometalate}

Polyoxometalates (POMs) are a class of inorganic cluster materials that are composed of early transition metal ions (Ms) coordinated with oxygen atoms (Os) and heteroatoms (Ps), which could be presented as $\left[\mathrm{X}_{\mathrm{x}} \mathrm{M}_{\mathrm{y}} \mathrm{O}_{\mathrm{z}}\right]^{\mathrm{n}-}[174,175]$. This kind of materials have drawn significant attention in the lithium-ion battery field due to their high capacities, thermal stabilities, diverse structures and various kinds of heteroatom doping $[176,177]$.

The binder could impede ion and charge transfer of the electrode. Liu et al. (2020) [178] prepared a bind-free POM-based membrane CDI electrode by electrodeposition of $\mathrm{SiW}_{12} \mathrm{O}_{40}{ }^{4-}\left(\mathrm{SiW}_{12}\right)$ and PANI (Polyaniline), thus forming $\mathrm{SiW}_{12} / \mathrm{PANI}$ composite. $\mathrm{SiW}_{12} / \mathrm{PANI}$ exhibited a high specific capacitance of $298 \mathrm{~F} \cdot \mathrm{g}^{-1}$ at $1 \mathrm{~A} \cdot \mathrm{g}^{-1}$ in $1 \mathrm{M} \mathrm{NaCl}$ solution and remained at $205 \mathrm{~F} \cdot \mathrm{g}^{-1}$ at $20 \mathrm{~A} \cdot \mathrm{g}^{-1}$, which also indicated a good rate ability. The composite showed a salt removal capacity of $23.1 \mathrm{mg} \cdot \mathrm{g}^{-1}$ in $500 \mathrm{ppm} \mathrm{NaCl}$ solution and barely decreased after 30 cycles, which was 33.5\% higher than that of pure PANI due to the synergistic effect of the POM and conducting polymers.

Another binder-free POM-based electrode was prepared by Liu et al. (2020) [179] with a similar method of electrochemical deposition of $\mathrm{P}_{2} \mathrm{Mo}_{18} \mathrm{O}_{62}{ }^{6-}\left(\mathrm{P}_{2} \mathrm{Mo}_{18}\right)$ and PPy (Polypyrrole). The as-prepared $\mathrm{P}_{2} \mathrm{Mo}_{18} / \mathrm{PPy}$ composite was the material for both electrodes in the membrane CDI system and exhibited 
a desalination capacity of $17.8 \mathrm{mg} \cdot \mathrm{g}^{-1}$ and a specific capacity of $156.2 \mathrm{mAh} \cdot \mathrm{g}^{-1}$, which were $49.6 \%$ and 79.7\% higher than those of pure PPy.

\section{Cl-Ion Battery Materials}

The process of desalination is related to both sodium and chloride ions. Enhancing the adsorption of the $\mathrm{Cl}^{-}$could also be an approach to improving the desalination capacity of the CDI system. The chloride ion batteries are attractive due to the low cost, good electrochemical performances and high energy density $[180,181]$. Employing the chloride ion battery materials as CDI electrodes might be a choice of higher significance.

\subsection{Bi-Based Material}

Bismuth is a green, economical material with a high chloride storage capacity, storing the chloride ions in the form of $\mathrm{BiOCl}$ via a reversible oxidation reaction [182,183].

Chang et al. (2020) [184] employed commercially purchased bismuth as a chloride adsorption electrode and activated carbon as the sodium adsorption electrode in the HCDI system without ion-exchange membranes with $500 \mathrm{mg} \cdot \mathrm{L}^{-1} \mathrm{NaCl}$ solution as the electrolyte. When the system was charged with a voltage of $1.2 \mathrm{~V}$, the chloride ions were adsorbed onto the bismuth material forming $\mathrm{BiOCl}$ and would be released into the solution the other way around. Meanwhile, the sodium ions were adsorbed and released by the activated carbon according to the electrical double-layer behavior. The bismuth material exhibited a high salt removal capacity of $55.52 \mathrm{mg} \cdot \mathrm{g}^{-1}$, nearly three times of that of activated carbon, but only remained at $74 \%$ after 10 cycles, which could presumably be due to the low conductivity and slow ion transfer.

Nam et al. (2018) [185] constructed a CDI system with only Bi-based materials as electrodes to reveal the mechanism of $\mathrm{Cl}$ storage of bismuth, in which $\mathrm{Bi}$ was employed as the anode and $\mathrm{BiOCl}$ was employed as the cathode as shown in Figure 8. The desalination energy consumption was low because equilibrium voltage was $0 \mathrm{~V}$ due to the reversible reaction of the electrode pair. The whole system was divided into two compartments by cation-exchange membrane or three compartments by cation and anion-exchange membranes. The brine was desalinated in the anode part of the two-compartment cell or in the middle part of the three-compartment cell. When the same amount of charge passed through, the latter would remove more ions than the former because the reversible formation of $\mathrm{BiOCl}$ was a process not only adsorbing $\mathrm{Cl}^{-}$but also producing $\mathrm{H}^{+}$, which was also the reason why a low $\mathrm{PH}$ could lower the operating voltage of the system.
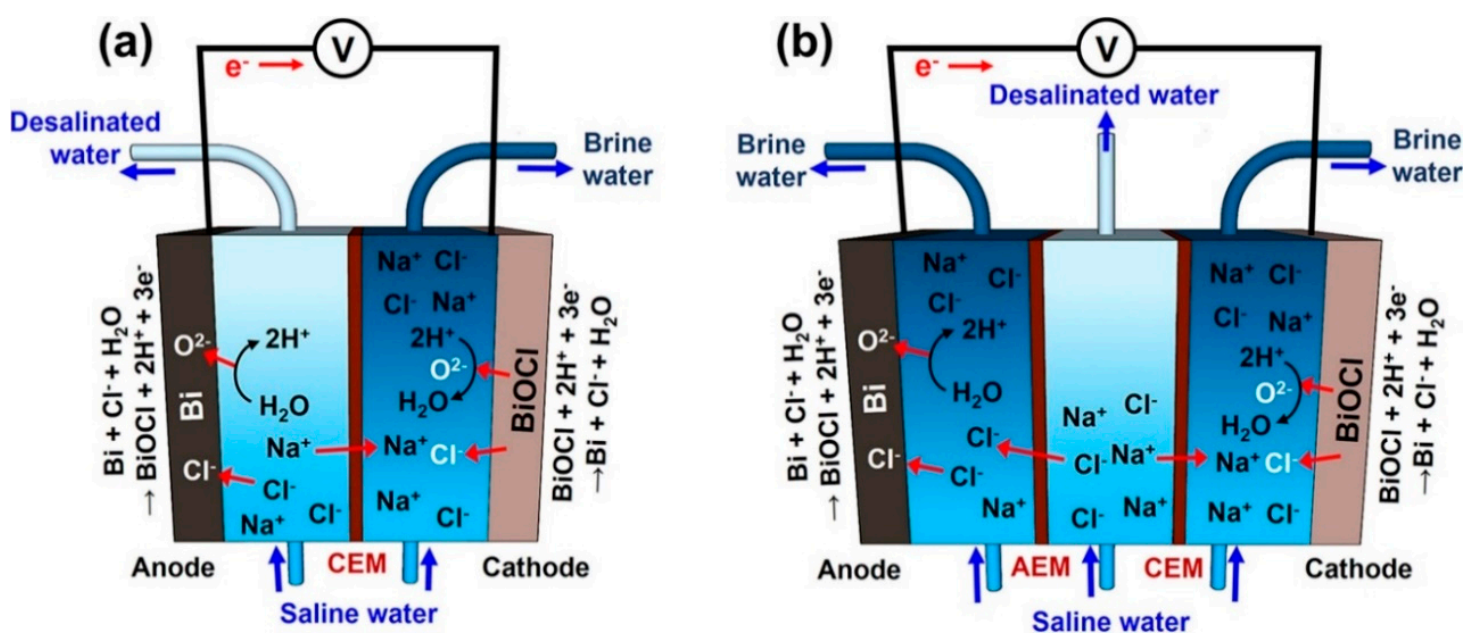

Figure 8. Two (a) and three (b) channel $\mathrm{Bi}|| \mathrm{BiOCl}$ chloride ion intercalation CDI system. Reproduced with permission from Ref. [181]. Copyright 2018 American Chemical Society. 
Chen et al. (2017) [186] coupled the bismuth with the sodium intercalation material NMO to form an electrode pair in the CDI system. During the salt release process, the system showed a high and stable salt removal capacity of $68.5 \mathrm{mg} \cdot \mathrm{g}^{-1}$ at the current density of $0.1 \mathrm{~A} \cdot \mathrm{g}^{-1}$ within 50 cycles with a high charge efficiency of $95.4 \%$.

\subsection{Ag-Based Material}

Silver is a battery material for chloride storage which has been studied for a long time due to its high theoretical capacity (about $235 \mathrm{mAh} \cdot \mathrm{g}^{-1}$ ) and fast kinetics, while the cost is non-negligible [187].

Tsai et al. (2016) [188] used Ag as the anode in the HCDI system with hierarchically ordered mesoporous carbon as the cathode. The Ag nanoparticles were commercially purchased and the mesoporous carbon was prepared from sugarcane bagasse. Chloride ions and sodium ions were adsorbed by anode and cathode when the system was charged. The system exhibited a salt removal capacity of $20.82 \mathrm{mg} \cdot \mathrm{g}^{-1}$, which was 2.4 times of that of the symmetric CDI system with two carbon electrodes. Silver ions could be released from the anode and be reduced to Ag nanoparticles onto the surface of the cathode, thus improving the deionization efficiency.

Zhang et al. (2020) [189] synthesized Ag/C material by annealing the Ag-doped hollow ZIF-8 precursor, which was employed as the anode in the HCDI system with a cation-exchange membrane. The hollow ZIF-8 (HZIF) precursor was prepared by tannic acid etching of the MOF material ZIF-8, which was selected due to its stable structure and nice porosity. Tannic acid not only enhanced the porosity of the material thus providing ion diffusion tunnels and active sites but also reduced silver ions on the surface of the material. In contrast, a symmetric CDI system was built with two electrodes of porous carbon, which was also the cathode material in the HCDI system synthesized by pyrolysis of HZIF precursor. The HCDI system exhibited a salt removal capacity of $19.81 \mathrm{mg} \cdot \mathrm{g}^{-1}$ in the $100 \mathrm{ppm} \mathrm{NaCl}$ solution and barely decreased during 20 cycles, which was $62.6 \%$ higher than that of the contrast system.

Ahn et al. (2020) [190] employed $\mathrm{Ag}$ and $\mathrm{AgCl}$ as the electrodes in the CDI system with a cation-exchange membrane separating them in the $500 \mathrm{ppm} \mathrm{NaCl}$ solution. When the system was charged, $\mathrm{Cl}^{-}$was adsorbed by $\mathrm{Ag}$ electrode to form $\mathrm{AgCl}$ and released from the $\mathrm{AgCl}$ electrode on the other side while the membrane blocked the anions but allowed the cations to pass through. The Ag material was commercially purchased without further purification and the $\mathrm{AgCl}$ electrode was prepared by electrochemical oxidation of the Ag electrode. The system exhibited a high desalination capacity of approximately $85 \mathrm{mg} \cdot \mathrm{g}^{-1}$ under constant current mode with a low charged voltage of less than $0.2 \mathrm{~V}$, which was energy efficient.

In a similar study, Srimuk et al. (2019) [191] constructed a CDI system where Ag and AgCl were used as the chloride storage electrodes. Ag nanoparticles were commercially purchased and the $\mathrm{AgCl}$ electrode was prepared by electrochemical chlorination of a carbon nanotube-coated Ag electrode. The CNT-coated $\mathrm{AgCl}$ electrode showed a specific capacity of $100 \mathrm{mAh} \cdot \mathrm{g}^{-1}$ and remained stable over 100 cycles while the Ag electrode retained only $81 \%$ of the initial capacity, indicating the advantage provided by CNT network. The system exhibited an ultrahigh salt removal capacity of $176-190 \mathrm{mg} \cdot \mathrm{g}^{-1}$ in the first cycle but only retained $115 \mathrm{mg}^{-1}$ after 15 cycles, whose capacity decay might be due to the irreversible formation of the positive electrode without CNT coating.

\section{Conducting Polymers}

Conducting polymers are a class of polymer materials which have highly conjugated $\pi-\pi$ structures and electronic, magnetic, optic properties similar to metals [192,193]. Conducting polymer materials consist of the conjugated chain structures and anions from $\mathrm{p}$-doping or cations from $\mathrm{n}$-doping. The conjugated chains provided tunnels for ion transfer, which is also enhanced by the doping ions. Conducting polymers have been widely reported as battery electrodes due to their controllable conductivity, high mechanical stability, lightweight and low cost [194,195]. Here are some works about conducting polymers in CDI. 


\subsection{Polypyrrole}

Polypyrrole (PPy) is the most commonly studied polymer material in CDI experiments owing to its easy synthesis and good conductivity after doping. The ion-exchange process could occur during the fast charge/discharge process inside and on the surface of the PPy, leading to a high desalination capacity $[196,197]$.

Feng et al. (2015) [198] synthesized a sponge-like hydro-PPy material via oxidation and acidification, which was used as the CDI electrode with graphite as the counter-electrode. The material exhibited an outstanding salt removal capacity of $2917.66 \mathrm{mg} \cdot \mathrm{g}^{-1}$ in the $35,000 \mathrm{ppm} \mathrm{Na}{ }^{+}$solution.

The combination of polymers and carbon materials could offer a platform to integrate high capacity with high conductivity. Wang et al. (2015) [199] prepared PPy/CNT CDI electrodes with the method of coating and compressing, respectively. The coated electrode showed a uniform surface structure and a lower charge transfer resistance than that of the compressed one. The coated PPy/CNT also exhibited an electrochemical capacitance of $180.61 \mathrm{~F} \cdot \mathrm{g}^{-1}$ and a salt removal capacity of $93.68 \mathrm{mg} \cdot \mathrm{g}^{-1}$, which were $57 \%$ and $37 \%$ higher than those of the compressed PPy/CNT. The optimum parameters of electrode coating were also studied, which were that the mass ratio of PVDF: graphite: active material was 1:1:8, the drying temperature was 40 degrees centigrade and the thickness of the coating was $0.3 \mathrm{~mm}$.

The electrodes with functional groups might have higher columbic efficiencies. Haq et al. (2020) [200] synthesized PPy/AC materials as CDI electrodes with sulfonic groups or amino groups by a room temperature polymerization reaction. The light grey coating layers of PPy surrounding the carbon cores were evident under SEM observation (Figure 9), which meant that the reduction of the surface area of the material was rapid. The deionization capacity of the PPy/AC was $18.4 \mathrm{mg} \cdot \mathrm{g}^{-1}$ and the columbic efficiency was $95 \%$, which were both nearly three times of those of conventional AC electrodes.

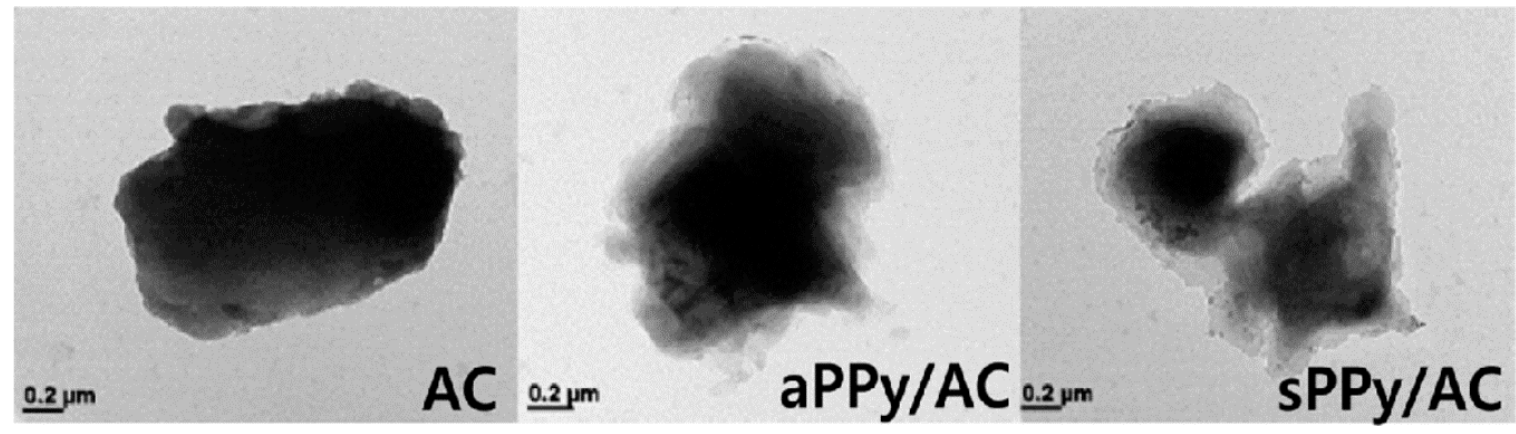

Figure 9. TEM images of AC, amino-PPy/AC and sulfonic acid-PPy/AC. Reproduced with permission from Ref. [196]. Copyright 2020 Springer Nature.

Xu et al. (2020) [201] prepared a PPy/GO composite by electrochemical polymerization using benzenesulfonic acid with the galvanostatic method as the CDI electrode in a membrane CDI system with graphite as the counter electrode. The structure was modulated by a CV method replacing benzenesulfonate dopants with choloride ions in $1 \mathrm{M} \mathrm{KCl}$ solution. The modulated PPy/GO had a cauliflower-fungus-shape structure and exhibited a high salt removal capacity of $88.43 \mathrm{mg} \cdot \mathrm{g}^{-1}$ in a $200 \mathrm{ppm} \mathrm{NaCl}$ solution, which was $50 \%$ higher than that of the material without modulation due to more active sites and less dense structure. It was also noticeable that the deionization capacity decreased while the initial salt concentration increased, which was owing to the co-ion effect.

\subsection{Polyaniline}

Polyaniline (PANI) is another well-known conducting polymer due to its easy synthesis, high capacity, low cost, environmental stability, processability and better mechanical properties than PPy [202,203]. PANI has abundant amine and imine groups that could lead to better CDI performance. 
Yan et al. (2014) [204] incorporated PANI into graphene sheets by ultrasonication and graphene/PANI nanocomposite was formed. The composite was used as active materials of both electrodes in the CDI system with cation and anion-exchange membranes. PANI grew on the edge of the graphene sheets and the amide groups connected the two materials, forming a larger $\pi-\pi$ conjugated system, enhancing the charge transferring. The salt removal capacity of the graphene/PANI was $9.3 \%$ and $25 \%$ higher than that of graphene in the $\mathrm{NaCl}$ solution with the initial conductivity of 500 and $1000 \mu \mathrm{s} \cdot \mathrm{cm}^{-1}$, respectively.

PPy could be more stable at different PH, the combination of PPy and PANI could produce better CDI performance. The PPy/PANI composite was synthesized with the in-situ oxidation polymerization method by Wang et al. (2015) [205] in an acid solution and used as the CDI electrode material coating with carbon nanotubes. With the $\mathrm{HClO}_{4}$ concentration of $1.5 \mathrm{M}$, the APS concentration of $0.575 \mathrm{M}$, the PPy/PANI mass ratio of $1: 1$ and the oxidant $\mathrm{FeCl}_{3}$ concentration of $0.2 \mathrm{M}$, the as-prepared composite exhibited a salt removal capacity of $197.8 \mathrm{mg} \cdot \mathrm{g}^{-1}$, which was 1.7 and 2.1 times of that of pure PPy and PANI, respectively. The composite was a mesoporous material with uniform morphologies.

Tian et al. (2017) [206] decorated the commercial purchased activated carbon fiber with PANI with an electrochemical polymerization method used as the electrodes in a symmetric CDI system. PANI grew homogeneously on the surface of the fibers and enlarged the surface area of the material, which provided abundant sites for charge storage. The ACF/PANI material exhibited a salt removal capacity of $19.9 \mathrm{mg} \cdot \mathrm{g}^{-1}$ in a $500 \mathrm{ppm} \mathrm{NaCl}$ solution at the voltage of $2 \mathrm{~V}$ and barely decreased after 28 cycles, which was nearly four times of that of undecorated carbon fiber. The ACF/PANI also showed a larger specific capacitance and a lower charge transfer resistance.

PANI/AC with amino groups (aPANI/AC) and PANI/AC with sulfonic groups (sPANI/AC) were synthesized by ul Haq et al. (2020) [207] through in-situ oxidation polymerization and were used as the two electrodes in the CDI system. The activated carbon was coated with layers of PANI with functional groups (fPANI) thus reducing the surface area of the material dramatically by replacing the micropores with mesopores. The fPANI electrode exhibited a salt removal capacity of $17.7 \mathrm{mg} \cdot \mathrm{g}^{-1}$ and a charge efficiency of $90 \%$, which were $160 \%$ and $137 \%$ higher than those of AC electrode due to enhanced ion diffusion because of mesopores and better conductivity, and were $20 \%$ and $5 \%$ higher than those of the PANI/AC without functional groups due to the attraction and repelling of the counter-ions and co-ions by the functional groups.

\section{Radical Polymers}

Radical polymers are a kind of polymer with stable N-O radical groups [208]. Poly (2,2,6,6tetramethylpiperidinyloxy methacrylate) (PTMA) is the most studied radical polymer and is used as the cathode in lithium-ion batteries, which has the properties of high theoretical capacity $\left(111 \mathrm{mAh} \cdot \mathrm{g}^{-1}\right)$, structural stability, rapid charge/discharge process, long life cycle, low cost and environmental friendliness [209,210].

Li et al. (2020) [211] synthesized PTMA by polymerization of 2,2,6,6-tetramethylpiperidinyloxy methacrylate monomers under heat in the acid solution with a nitrogen atmosphere. The PTMA was used as the electrode in a membrane-free CDI system. The PTMA electrode exhibited a salt removal capacity of $20.9 \mathrm{mg} \cdot \mathrm{g}^{-1}$ at $1.2 \mathrm{~V}$ which maintained for 20 cycles and a specific capacity of $51 \mathrm{mAh} \cdot \mathrm{g}^{-1}$ at the current density of $0.1 \mathrm{~A} \cdot \mathrm{g}^{-1}$ in $1 \mathrm{M} \mathrm{NaCl}$ solution, which were both about twice those of activated carbon though they suffered from a worse wettability.

\section{Flow Battery Electrode Materials}

The literature about CDI battery electrodes mostly focuses on solid battery materials. However, the flow electrode battery materials could also exhibit good potential due to the ability to handle high concentration saline water and the high energy efficiency of the system.

Hou et al. (2018) [212] integrated the deionization process with the discharging process of the flow electrode battery, which consisted of a $\mathrm{VCl}_{3} / \mathrm{VCl}_{2}$ anolyte and a NaI catholyte (Figure 10). The whole system was divided into three compartments by the ion-exchange membranes. The saline water of 
$19,000 \mathrm{ppm} \mathrm{NaCl}$ was in the middle reservoir and was separated from anolyte and catholyte with anion-exchange membrane and cation-exchange membrane, respectively. When the discharging process occurred, the $\mathrm{V}^{2+}$ ions were oxidated into $\mathrm{V}^{3+}$ ions, thus driving the $\mathrm{Cl}^{-}$ions to pass through the membrane. Meanwhile, $\mathrm{Na}^{+}$ions were absorbed into the catholyte due to the reduction of $\mathrm{I}^{3-}$ ions into $\mathrm{I}^{-}$ions, similarly. The electrodes regenerated during the charge process. The system exhibited a stable salt removal capacity of $400 \mathrm{mg}$ per liter of the electrolyte, which could be calculated as $82.6 \mathrm{mg}$ per gram of electrode material. It was also noticeable that the energy consumption was $10.27 \mathrm{KJ} \cdot \mathrm{mol}^{-1}$ salt, which was $15 \%$ lower than traditional reverse osmosis technology.
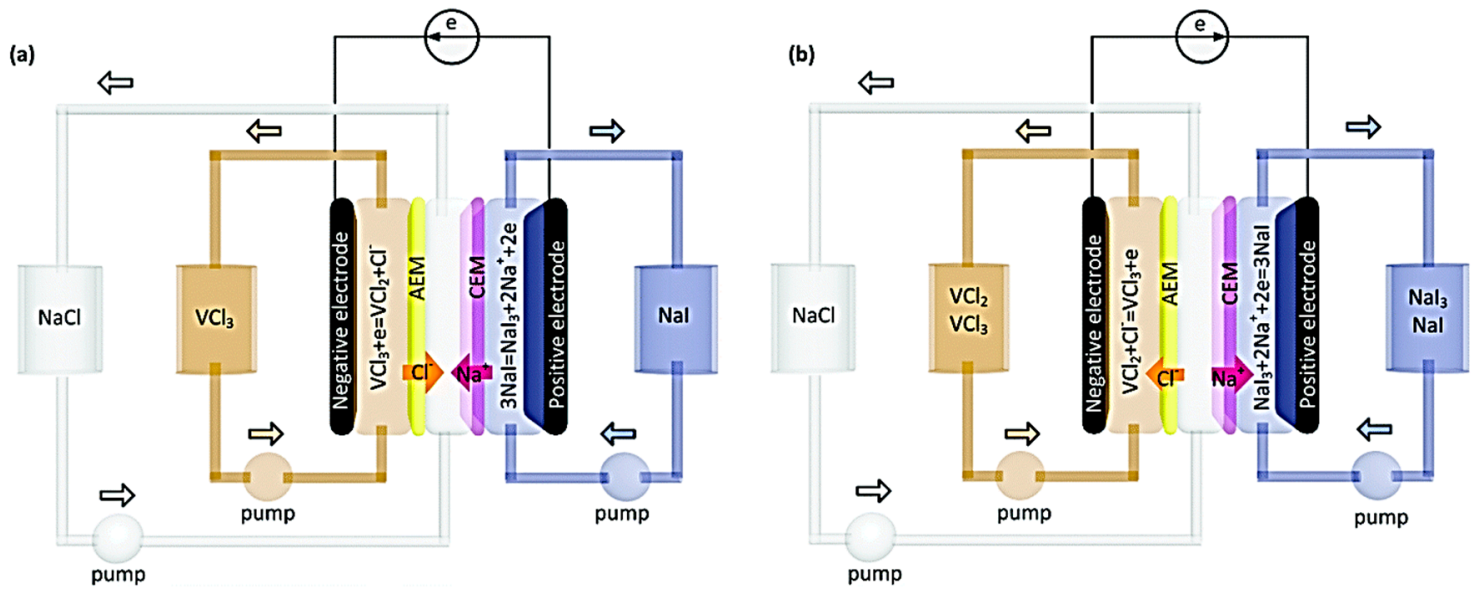

Figure 10. Regeneration (a) and desalination (b) processes of $\mathrm{NaI} \| \mathrm{VCl}_{3} / \mathrm{VCl}_{2}$ flow battery CDI system. Reproduced with permission from Ref. [212]. Copyright 2018 Royal Society of Chemistry.

Desai et al. (2018) [213] constructed a flow electrode battery for deionization with a configuration similar to the system above, utilizing $\mathrm{Zn} / \mathrm{ZnCl}_{2}$ as anode/anolyte and graphite/[ $\left.\mathrm{K}_{4} \mathrm{Fe}(\mathrm{CN})_{6}+\mathrm{K}_{3} \mathrm{Fe}(\mathrm{CN})_{6}\right]$ as the cathode/catholyte. The sodium and chloride ions were adsorbed through the membranes into the electrode due to the redox reactions during the discharging process and escaped back to the middle compartment during the charge process. Though the concentration of the saline water was high up to $100 \mathrm{~g} \cdot \mathrm{L}^{-1}$, the removal rate was still $86 \%$. The energy consumption of the system desalinating seawater into drinkable water was $3.47 \mathrm{Wh} \cdot \mathrm{L}^{-1}$, which was comparable to that of the reverse osmosis technology $\left(3-6 \mathrm{Wh} \cdot \mathrm{L}^{-1}\right)$.

\section{Conclusions}

Research on desalination has become a hotspot for many researchers, development experts, and government agencies. As such, this work attempts to provide a detailed review of the current state of battery materials as CDI electrodes for desalination. Table 1 has listed the materials and corresponding deionization performances, most of which have larger desalination capacities than those of carbon-based traditional electrode materials and could be used under the high salt concentrations of saline water. 
Table 1. Desalination performances and operation conditions of CDI battery electrode materials.

\begin{tabular}{|c|c|c|c|c|c|c|}
\hline NO. & Materials of the Electrode Pair & Initial $\mathrm{NaCl}$ Concentration & CC (Constant Current)/CV (Constant Voltage) & Current Density/Voltage & Desalination Capacity & Ref. \\
\hline 1 & $\mathrm{Na}_{4} \mathrm{Mn}_{9} \mathrm{O}_{18} \| \mathrm{AC}$ & $50 \mathrm{mM}$ & $\mathrm{CV}$ & $1.2 \mathrm{~V}$ & $31.2 \mathrm{mg} \cdot \mathrm{g}^{-1}$ & [79] \\
\hline 2 & $\mathrm{Na}_{0.44} \mathrm{MnO}_{2} \| \mathrm{AgCl}$ & $890 \mathrm{mg} \cdot \mathrm{L}^{-1}$ & $\mathrm{CC}$ & $0.1 \mathrm{~A} \cdot \mathrm{g}^{-1}$ & $57.4 \mathrm{mg} \cdot \mathrm{g}^{-1}$ & [80] \\
\hline 3 & $\mathrm{MnO}_{2} / \mathrm{CNT} \| \mathrm{AC}$ & $30 \mathrm{mg} \cdot \mathrm{L}^{-1}$ & $\mathrm{CV}$ & $1.8 \mathrm{~V}$ & $6.65 \mathrm{mg} \cdot \mathrm{g}^{-1}$ & [83] \\
\hline 4 & $\begin{array}{l}\alpha-\mathrm{MnO}_{2} \| \mathrm{AC} \\
\delta-\mathrm{MnO}_{2} \| \mathrm{AC}\end{array}$ & $5 \mathrm{mM}$ & $\mathrm{CV}$ & $1 \mathrm{~V}$ & $\begin{array}{l}9.93 \mathrm{mg} \cdot \mathrm{g}^{-1} \\
9.35 \mathrm{mg} \cdot \mathrm{g}^{-1}\end{array}$ & [84] \\
\hline 5 & $\beta-\mathrm{MnO}_{2} \|$ carbon & $1 \mathrm{mM}$ & $\mathrm{CV}$ & $1.8 \mathrm{~V}$ & about $18.4 \mathrm{mg} \cdot \mathrm{g}^{-1}$ & [85] \\
\hline 6 & $\mathrm{Na}_{0.71} \mathrm{CoO}_{2} \| \mathrm{Ag} / \mathrm{rGO}$ & $500 \mathrm{mg} \cdot \mathrm{L}^{-1}$ & $\mathrm{CV}$ & $1.4 \mathrm{~V}$ & $31 \mathrm{mg} \cdot \mathrm{g}^{-1}$ & [89] \\
\hline 7 & $\mathrm{Na}_{0.27} \mathrm{Ca}_{0.03} \mathrm{CoO}_{2} \| \mathrm{AC}$ & $529 \mathrm{mg} \cdot \mathrm{L}^{-1}$ & $\mathrm{CV}$ & $1.4 \mathrm{~V}$ & $83.5 \pm 2.4 \mathrm{mg} \cdot \mathrm{g}^{-1}$ & [90] \\
\hline 8 & $\mathrm{rGO} / \mathrm{TiO}_{2} \| \mathrm{rGO} / \mathrm{TiO}_{2}$ & $150 \mu \mathrm{S} \cdot \mathrm{cm}^{-1}$ & $\mathrm{CV}$ & $1.2 \mathrm{~V}$ & $24.576 \mathrm{mg} \cdot \mathrm{g}^{-1}$ & [94] \\
\hline 9 & $\mathrm{Na}_{4} \mathrm{Ti}_{9} \mathrm{O}_{20} / \mathrm{C} \| \mathrm{AC}$ & $500 \mu \mathrm{S} \cdot \mathrm{cm}^{-1}$ & $\mathrm{CV}$ & $1.4 \mathrm{~V}$ & $80.56 \mathrm{mg} \cdot \mathrm{g}^{-1}$ & [95] \\
\hline 10 & graphene/SnO $\mathrm{Sn}_{2}$ |lgraphene/ $/ \mathrm{SnO}_{2}$ & $61 \mu \mathrm{S} \cdot \mathrm{cm}^{-1}$ & $\mathrm{CV}$ & $1.4 \mathrm{~V}$ & $1.49 \mathrm{mg} \cdot \mathrm{g}^{-1}$ & {$[100$} \\
\hline 11 & $\mathrm{~N}-\mathrm{AC} / \mathrm{SnO}_{2} \| \mathrm{N}-\mathrm{AC} / \mathrm{SnO}_{2}$ & $50 \mathrm{mg} \cdot \mathrm{L}^{-1}$ & $\mathrm{CV}$ & $1.2 \mathrm{~V}$ & $3.42 \mathrm{mg} \cdot \mathrm{g}^{-1}$ & {$[101]$} \\
\hline 12 & $\mathrm{AC} \| \mathrm{ZnO} / \mathrm{AC}$ & $500 \mathrm{mg} \cdot \mathrm{L}^{-1}$ & $\mathrm{CV}$ & $1.2 \mathrm{~V}$ & $9.4 \mathrm{mg} \cdot \mathrm{g}^{-1}$ & {$[105$} \\
\hline 13 & graphene/CNT/ZnO||graphene/CNT/ZnO & $600 \mathrm{mg} \cdot \mathrm{L}^{-1}$ & $\mathrm{CV}$ & $1.2 \mathrm{~V}$ & $28.62 \mathrm{mg} \cdot \mathrm{g}^{-1}$ & {$[106]$} \\
\hline 14 & $\mathrm{Fe}_{3} \mathrm{O}_{4} / \mathrm{rGO} \| \mathrm{Fe}_{3} \mathrm{O}_{4} / \mathrm{rGO}$ & $110 \mu \mathrm{S} \cdot \mathrm{cm}^{-1}$ & $\mathrm{CV}$ & $1.5 \mathrm{~V}$ & $4.3 \mathrm{mg}^{-1} \mathrm{~g}^{-1}$ & [111] \\
\hline 15 & $\mathrm{NiCO}_{2} \mathrm{O}_{4} \| \mathrm{AC}$ & $1000 \mu \mathrm{S} \cdot \mathrm{cm}^{-1}$ & $\mathrm{CV}$ & $1.2 \mathrm{~V}$ & $44.3 \mathrm{mg} \cdot \mathrm{g}^{-1}$ & {$[116$} \\
\hline 16 & $\mathrm{MnFe}_{2} \mathrm{O}_{4} / \mathrm{rGO} \| \mathrm{MnO}_{2} / \mathrm{rGO}$ & $50 \mathrm{mg} \cdot \mathrm{L}^{-1}$ & $\mathrm{CV}$ & $1.6 \mathrm{~V}$ & $38.28 \mathrm{mg} \cdot \mathrm{g}^{-1}$ & {$[121]$} \\
\hline 17 & $\mathrm{AC} \| \mathrm{NaTi}_{2}\left(\mathrm{PO}_{4}\right)_{3} / \mathrm{rGO}$ & $1000 \mathrm{mg} \cdot \mathrm{L}^{-1}$ & CC & $0.1 \mathrm{~A} \cdot \mathrm{g}^{-1}$ & $140{\mathrm{mg} \cdot \mathrm{g}^{-1}}^{-1}$ & {$[128]$} \\
\hline 18 & $\mathrm{~N}, \mathrm{~S}-\mathrm{NaTi}_{2}\left(\mathrm{PO}_{4}\right)_{3} /$ hole rGO $\| \mathrm{AC}$ & $800 \mathrm{mg} \cdot \mathrm{L}^{-1}$ & $\mathrm{CV}$ & $1.4 \mathrm{~V}$ & $36.87 \mathrm{mg} \cdot \mathrm{g}^{-1}$ & {$[131]$} \\
\hline 19 & $\mathrm{Ag} / \mathrm{rGO} \| \mathrm{NaTi}_{2}\left(\mathrm{PO}_{4}\right)_{3} / \mathrm{rGO}$ & $2500 \mathrm{mg} \cdot \mathrm{L}^{-1}$ & $\mathrm{CC}$ & $0.1 \mathrm{~A} \cdot \mathrm{g}^{-1}$ & $105 \mathrm{mg} \cdot \mathrm{g}^{-1}$ & {$[132]$} \\
\hline 20 & $\mathrm{Ag} \| \mathrm{NaTi}_{2}\left(\mathrm{PO}_{4}\right)_{3}$ & $1 \mathrm{M}$ & - & $\underline{-}$ & $151.5 \mathrm{mg} \cdot \mathrm{g}^{-1}$ & {$[133$} \\
\hline 21 & $\mathrm{Na}_{3} \mathrm{~V}_{2}\left(\mathrm{PO}_{4}\right)_{3} / \mathrm{C} \| \mathrm{AC}$ & $100 \mathrm{mM}$ & $\mathrm{CV}$ & $1 \mathrm{~V}$ & $137.2 \mathrm{mg} \cdot \mathrm{g}^{-1}$ & [137] \\
\hline 22 & $\mathrm{Na}_{3} \mathrm{~V}_{2}(\mathrm{PO} 4)_{3} / \mathrm{rGO} \| \mathrm{AgCl} / \mathrm{rGO}$ & $1000 \mathrm{mg} \cdot \mathrm{L}^{-1}$ & $\mathrm{CC}$ & $0.1 \mathrm{~A} \cdot \mathrm{g}^{-1}$ & $107.5 \mathrm{mg} \cdot \mathrm{g}^{-1}$ & {$[139]$} \\
\hline 23 & $\mathrm{Na}_{2} \mathrm{FeP}_{2} \mathrm{O}_{7} / \mathrm{C} \| \mathrm{AC}$ & $100 \mathrm{mM}$ & $\mathrm{CV}$ & $1.2 \mathrm{~V}$ & $32.6 \mathrm{mg} \cdot \mathrm{g}^{-1}$ & [141] \\
\hline 24 & $\mathrm{NaNiHCF} \mid \mathrm{NaFeHCF}$ & $0.5 \mathrm{M}$ & $\mathrm{CC}$ & $0.5 \mathrm{~mA} \cdot \mathrm{cm}^{-2}$ & $39.9 \mathrm{mg} \cdot \mathrm{g}^{-1}$ & {$[146$} \\
\hline 25 & $\mathrm{NaNiFe}(\mathrm{CN})_{6} \| \mathrm{Na}_{2} \mathrm{NiFe}(\mathrm{CN})_{6}$ & $20 \mathrm{mM}$ & CC & $0.28 \mathrm{~mA} \cdot \mathrm{cm}^{-2}$ & $34{\mathrm{mg} \cdot \mathrm{g}^{-1}}^{-1}$ & {$[147$} \\
\hline 26 & $\mathrm{FeFe}(\mathrm{CN})_{6} / \mathrm{rGO} \| \mathrm{AC}$ & $1937 \mu \mathrm{S} \cdot \mathrm{cm}^{-1}$ & CC & $0.125 \mathrm{~A} \cdot \mathrm{g}^{-1}$ & $120 \mathrm{mg} \cdot \mathrm{g}^{-1}$ & [66] \\
\hline 27 & $\mathrm{FePO}_{4} / \mathrm{rGO} \| \mathrm{AC}$ & $2500 \mathrm{mg} \cdot \mathrm{L}^{-1}$ & $\mathrm{CC}$ & $0.1 \mathrm{~A} \cdot \mathrm{g}^{-1}$ & $100 \mathrm{mg}^{-1} \mathrm{~g}^{-1}$ & {$[153$} \\
\hline 28 & $\mathrm{FePO}_{4} / \mathrm{rGO} \| \mathrm{rGO}$ & $40 \mathrm{mM}$ & $\mathrm{CV}$ & $1.8 \mathrm{~V}$ & $85.94 \mathrm{mg} \cdot \mathrm{g}^{-1}$ & {$[154]$} \\
\hline 29 & $\mathrm{MoS}_{2} / \mathrm{CNT}|| \mathrm{MoS}_{2} / \mathrm{CNT}$ & $500 \mathrm{mM}$ & $\mathrm{CV}$ & $0.8 \mathrm{~V}$ & $25 \mathrm{mg} \cdot \mathrm{g}^{-1}$ & {$[157]$} \\
\hline 30 & Defect-rich $\mathrm{MoS}_{2} \|$ Defect-rich $\mathrm{MoS}_{2}$ & $254.35 \mathrm{mg} \cdot \mathrm{L}^{-1}$ & $\mathrm{CV}$ & $0.8 \mathrm{~V}$ & $24.6 \mathrm{mg} \cdot \mathrm{g}^{-1}$ & {$[158$} \\
\hline 31 & $\mathrm{AC} \mid \mathrm{MoS}_{2} / \mathrm{PDA}$ & $200 \mathrm{mg} \cdot \mathrm{L}^{-1}$ & $\mathrm{CV}$ & $1.2 \mathrm{~V}$ & $14.8 \mathrm{mg} \cdot \mathrm{g}^{-1}$ & {$[159$} \\
\hline 32 & Ar-modified $\mathrm{Ti}_{3} \mathrm{C}_{2} \mathrm{~T}_{\mathrm{x}} \| \mathrm{AC}$ & $500 \mathrm{mg} \cdot \mathrm{L}^{-1}$ & $\mathrm{CV}$ & $1.2 \mathrm{~V}$ & $26.8 \mathrm{mg} \cdot \mathrm{g}^{-1}$ & {$[163]$} \\
\hline 33 & Porous $\mathrm{Ti}_{3} \mathrm{C}_{2} \mathrm{~T}_{\mathrm{x}} \|$ Porous $\mathrm{Ti}_{3} \mathrm{C}_{2} \mathrm{~T}_{\mathrm{x}}$ & $10,000 \mathrm{mg} \cdot \mathrm{L}^{-1}$ & $\mathrm{CV}$ & $1.2 \mathrm{~V}$ & $45 \mathrm{mg}^{-1}$ & {$[164$} \\
\hline 34 & $\mathrm{NH}_{4} \mathrm{~V}_{4} \mathrm{O}_{10} / \mathrm{rGO} \| \mathrm{AC}$ & $500 \mathrm{mg} \cdot \mathrm{L}^{-1}$ & $\mathrm{CV}$ & $1.2 \mathrm{~V}$ & $20.1 \mathrm{mg} \cdot \mathrm{g}^{-1}$ & {$[165$} \\
\hline 35 & $\mathrm{Li}_{4} \mathrm{Ti}_{5} \mathrm{O}_{12} / \mathrm{C} \|$ carbon cloth & $2500 \mathrm{mg} \cdot \mathrm{L}^{-1}$ & $\mathrm{CC}$ & $0.16 \mathrm{~mA} \cdot \mathrm{cm}^{-2}$ & $25 \mathrm{mg}^{-1}$ & {$[173]$} \\
\hline 36 & $\mathrm{SiW}_{12} /$ PANI/graphite & $500 \mathrm{mg} \cdot \mathrm{L}^{-1}$ & $\mathrm{CV}$ & $1.2 \mathrm{~V}$ & $23.1 \mathrm{mg} \cdot \mathrm{g}^{-1}$ & {$[178$} \\
\hline 37 & $\mathrm{P}_{2} \mathrm{Mo}_{18} /$ PPy/graphite & $600 \mathrm{mg} \cdot \mathrm{L}^{-1}$ & $\mathrm{CV}$ & $1.2 \mathrm{~V}$ & $17.8 \mathrm{mg} \cdot \mathrm{g}^{-1}$ & [179] \\
\hline 38 & $\mathrm{AC} \| \mathrm{Bi}$ & $500 \mathrm{mg} \cdot \mathrm{L}^{-1}$ & $\mathrm{CV}$ & $1.2 \mathrm{~V}$ & $55.52 \mathrm{mg}^{-1} \mathrm{~g}^{-1}$ & {$[184$} \\
\hline 39 & $\mathrm{Na}_{0.44} \mathrm{MnO}_{2} \| \mathrm{BiOCl}$ & $760 \mathrm{mg} \cdot \mathrm{L}^{-1}$ & CC & $0.1 \mathrm{~A} / \mathrm{g}$ & $68.5 \mathrm{mg} \cdot \mathrm{g}^{-1}$ & [186] \\
\hline
\end{tabular}


Table 1. Cont.

\begin{tabular}{|c|c|c|c|c|c|c|}
\hline NO. & Materials of the Electrode Pair & Initial $\mathrm{NaCl}$ Concentration & CC (Constant Current)/CV (Constant Voltage) & Current Density/Voltage & Desalination Capacity & Ref. \\
\hline 40 & mesoporous carbon $\| \mathrm{Ag}$ & $1 \mathrm{mM}$ & $\mathrm{CV}$ & $1.2 \mathrm{~V}$ & $20.82 \mathrm{mg} \cdot \mathrm{g}^{-1}$ & {$[188$} \\
\hline 41 & hollow carbon $\| \mathrm{Ag} / \mathrm{C}$ & $500 \mathrm{mg} \cdot \mathrm{L}^{-1}$ & $\mathrm{CV}$ & $1.2 \mathrm{~V}$ & $29.18 \mathrm{mg} \cdot \mathrm{g}^{-1}$ & {$[189]$} \\
\hline 42 & $\mathrm{AgCl}|| \mathrm{Ag}$ & $500 \mathrm{mM}$ & $\mathrm{CC}$ & $1 \mathrm{~mA} \cdot \mathrm{cm}^{-2}$ & $85 \mathrm{mg} \cdot \mathrm{g}^{-1}$ & {$[190$} \\
\hline 43 & $\mathrm{AgCl} \| \mathrm{Ag}$ & $600 \mathrm{mM}$ & $\mathrm{CC}$ & $0.1{\mathrm{~A} \cdot \mathrm{g}^{-1}}^{-1}$ & $115 \mathrm{mg} \cdot \mathrm{g}^{-1}$ & {$[191]$} \\
\hline 44 & hydro-PPyllgraphite & $88,930.43 \mathrm{mg} \cdot \mathrm{L}^{-1}$ & $\mathrm{CV}$ & $2 \mathrm{~V}$ & $2917.66 \mathrm{mg} \cdot \mathrm{g}^{-1}$ & [198 \\
\hline 45 & graphite||PPy/CNT & $1000 \mu \mathrm{S} \cdot \mathrm{cm}^{-1}$ & $\mathrm{CV}$ & $1.4 \mathrm{~V}$ & $93.68 \mathrm{mg} \cdot \mathrm{g}^{-1}$ & [199] \\
\hline 46 & $\mathrm{NH}_{2}-\mathrm{PPy} / \mathrm{AC} \| \mathrm{HSO}_{3}-\mathrm{PPy} / \mathrm{AC}$ & $8.55 \mathrm{mM}$ & $\mathrm{CV}$ & $1 \mathrm{~V}$ & $18.4 \mathrm{mg} \cdot \mathrm{g}^{-1}$ & {$[200]$} \\
\hline 47 & $\begin{array}{l}\text { GO/PPy |GO/PPy } \\
\text { GOP }\end{array}$ & $200 \mathrm{mg} \cdot \mathrm{L}^{-1}$ & $\mathrm{CV}$ & $1.2 \mathrm{~V}$ & $88.43 \mathrm{mg} \cdot \mathrm{g}^{-1}$ & [201] \\
\hline 48 & CNT||PPy/PANI & $500 \mathrm{mg} \cdot \mathrm{L}^{-1}$ & $\mathrm{CV}$ & $1.4 \mathrm{~V}$ & $197.8 \mathrm{mg} \cdot \mathrm{g}^{-1}$ & [205] \\
\hline 49 & AC/PANI|AC/PANI & $200 \mathrm{mg} \cdot \mathrm{L}^{-1}$ & $\mathrm{CV}$ & $2 \mathrm{~V}$ & $19.9 \mathrm{mg} \cdot \mathrm{g}^{-1}$ & {$[206$} \\
\hline 50 & $\mathrm{NH}_{2}$-PANI/AC $\| \mathrm{HSO}_{3}$-PANI/AC & $8.55 \mathrm{mM}$ & $\mathrm{CV}$ & $1 \mathrm{~V}$ & $17.7 \mathrm{mg} \cdot \mathrm{g}^{-1}$ & {$[207]$} \\
\hline 51 & AC |PTMA & $250 \mathrm{mg} \cdot \mathrm{L}^{-1}$ & $\mathrm{CV}$ & $1.2 \mathrm{~V}$ & $20.9 \mathrm{mg} \cdot \mathrm{g}^{-1}$ & {$[211]$} \\
\hline 52 & $\mathrm{NaI}|| \mathrm{VCl}_{3} / \mathrm{VCl}_{2}$ & $19,000 \mathrm{mg} \cdot \mathrm{L}^{-1}$ & $\mathrm{CC}$ & $0.22 \mathrm{~mA} \cdot \mathrm{cm}^{-2}$ & $82.6 \mathrm{mg} \cdot \mathrm{g}^{-1}$ & {$[212]$} \\
\hline
\end{tabular}


Desalination is a process of extracting sodium and chloride ions out of the solution, so without doubt the sodium and chloride-ion battery materials should play important roles in the CDI systems. Compared to chloride-ion battery materials, the sodium-ion battery materials have drawn greater attention and impetus in research because of the larger energy density and power density, resulting in a large family of sodium-ion battery materials appearing in the literature of CDI, many of which exhibit good desalination performances. The research of chloride-ion battery materials is relatively limited to the Bi-based and Ag-based materials because of the poor affinity of chloride to other materials. However, lithium-ion battery materials have greater potential of application in the desalination industry because these materials have already been in large scale production, unlike other battery materials. Lithium ion battery materials on the other hand have similar electrochemical behaviors to sodium ion battery materials and could exhibit good desalination capacities, which is worthy of further exploration. The three categories mentioned above all share the intercalation behavior of ions thus often leading to the collapse of the crystalline structures after desalination cycles. Especially for the sodium ion battery cathodes, the sodiation and de-sodiation processes and the formation of $\mathrm{NaOH}$ could cause severe degradation of the electrodes, leading to the decay of the electrochemical and desalination capacities. The promoting of the cyclabilities of these battery materials remains necessary. Besides, the voltage plateau should be within the voltage window of water during the selection of materials in case of the side reactions and waste of energy. Polymers could exhibit high desalination capacities and good cycling performances and handle saline water of high concentration, indicating ideal CDI electrode materials. PPy and PANI are the most studied conducting polymers in the literature while the small scale of industrial production limits their real application. Flow battery electrode materials have also been utilized in CDI tests and showed good deionization performances, the energy consumption of which was competitive. Various kinds of battery materials have been reported in the CDI research and show good CDI performances. Lithium battery materials and conducting polymers are the most promising among the battery materials in CDI due to the easy accessibility and ideal electrochemical properties, respectively. On the whole, original battery materials have larger desalination capacities than capacitive materials, therefore they could handle higher concentration solutions, but they could only have a lifespan of tens of cycles. Battery materials and capacitive materials both have their own advantages and disadvantages. Capacitive materials like carbon materials have smaller capacities but robust cyclabilities and relatively low costs. It is wise to combine the advantages of the two kinds of materials together by incorporating battery materials with carbon-based materials. Many scientists did so and reported good results. The tendency of the research might be to find a green battery material that has a large capacity in the aqueous environment with appropriate stability and then incorporate it with carbonaceous material to get a longer cycle life; the mechanism behind this should be studied further. The battery materials provide CDI technology with a bright future of application.

Author Contributions: Conceptualization, Y.J. and H.W.; methodology, Y.J. and H.W.; validation, Y.J. and S.I.A.; formal analysis, D.W.; data curation, Y.J.; writing-original draft preparation, Y.J. and H.W.; writing-review and editing, Y.J., S.I.A. and H.W.; visualization, Y.J., S.I.A. and H.W.; supervision, H.W.; funding acquisition, Y.J. and H.W. All authors have read and agreed to the published version of the manuscript.

Funding: This research is funded by the Key R\&D Program of Hunan Province (2018SK2026), National Science Fund for Distinguished Young Scholars (51825403), National Key R\&D Program of China (2018YFC1900300) and the key projects of Science and Technology of Hunan Province (2017SK2420).

Conflicts of Interest: All authors declare no conflicts of interest.

\section{References}

1. Liu, J.G.; Mooney, H.; Hull, V.; Davis, S.J.; Gaskell, J.; Hertel, T.; Lubchenco, J.; Seto, K.C.; Gleick, P.; Kremen, C.; et al. Systems integration for global sustainability. Science 2015, 347, 10. [CrossRef] [PubMed]

2. De, S.; Balu, A.M.; van der Waal, J.C.; Luque, R. Biomass-Derived Porous Carbon Materials: Synthesis and Catalytic Applications. ChemCatChem 2015, 7, 1608-1629. [CrossRef] 
3. Schwarzenbach, R.P.; Egli, T.; Hofstetter, T.B.; Von Gunten, U.; Wehrli, B. Global Water Pollution and Human Health. In Annual Review of Environment and Resources; Gadgil, A., Liverman, D.M., Eds.; Annual Reviews: Palo Alto, SF, USA, 2010; Volume 35, pp. 109-136.

4. Oki, T.; Kanae, S. Global hydrological cycles and world water resources. Science 2006, 313, $1068-1072$. [CrossRef] [PubMed]

5. Elimelech, M.; Phillip, W.A. The Future of Seawater Desalination: Energy, Technology, and the Environment. Science 2011, 333, 712-717. [CrossRef]

6. Svoboda, P.; Janska, A.; Spiwok, V.; Prasil, I.T.; Kosova, K.; Vitamvas, P.; Ovesna, J. Global Scale Transcriptional Profiling of Two Contrasting Barley Genotypes Exposed to Moderate Drought Conditions: Contribution of Leaves and Crowns to Water Shortage Coping Strategies. Front. Plant Sci. 2016, 7, 17. [CrossRef]

7. Palmer, M.A.; Liu, J.G.; Matthews, J.H.; Mumba, M.; D’Odorico, P. Water security: Gray or green? Science 2015, 349, 584-585. [CrossRef]

8. Falkenmark, M. Growing water scarcity in agriculture: Future challenge to global water security. Philos. Trans. R. Soc. A-Math. Phys. Eng. Sci. 2013, 371, 14. [CrossRef]

9. Catley-Carlson, M. The Water Paradox: Overcoming the Global Crisis in Water Management. Nature 2019, 565, 426-427. [CrossRef]

10. Hejazi, M.; Edmonds, J.; Chaturvedi, V.; Davies, E.; Eom, J. Scenarios of global municipal water-use demand projections over the 21st century. Hydrol. Sci. J. 2013, 58, 519-538. [CrossRef]

11. De Graaf, I.E.M.; van Beek, L.P.H.; Wada, Y.; Bierkens, M.F.P. Dynamic attribution of global water demand to surface water and groundwater resources: Effects of abstractions and return flows on river discharges. Adv. Water Resour. 2014, 64, 21-33. [CrossRef]

12. Parkinson, S.C.; Johnson, N.; Rao, N.D.; Jones, B.; Van Vliet, M.T.H.; Fricko, O.; Djilali, N.; Riahi, K.; Florke, M. Climate and human development impacts on municipal water demand: A spatially-explicit global modeling framework. Environ. Model. Softw. 2016, 85, 266-278. [CrossRef]

13. Linares, R.V.; Li, Z.; Sarp, S.; Bucs, S.S.; Amy, G.; Vrouwenvelder, J.S. Forward osmosis niches in seawater desalination and wastewater reuse. Water Res. 2014, 66, 122-139. [CrossRef]

14. Gao, M.; Connor, P.K.N.; Ho, G.W. Plasmonic photothermic directed broadband sunlight harnessing for seawater catalysis and desalination. Energy Environ. Sci. 2016, 9, 3151-3160. [CrossRef]

15. Morillo, J.; Usero, J.; Rosado, D.; El Bakouri, H.; Riaza, A.; Bernaola, F.J. Comparative study of brine management technologies for desalination plants. Desalination 2014, 336, 32-49. [CrossRef]

16. Catrini, P.; Cipollina, A.; Micale, G.; Piacentino, A.; Tamburini, A. Exergy analysis and thermoeconomic cost accounting of a Combined Heat and Power steam cycle integrated with a Multi Effect Distillation-Thermal Vapour Compression desalination plant. Energy Conv. Manag. 2017, 149, 950-965. [CrossRef]

17. Wang, C.; Wang, L.; Wang, X.L.; Zhao, H.X. Design and numerical investigation of an adaptive nozzle exit position ejector in multi-effect distillation desalination system. Energy 2017, 140, 673-681. [CrossRef]

18. Sharan, P.; Neises, T.; Turchi, C. Optimal feed flow sequence for multi-effect distillation system integrated with supercritical carbon dioxide Brayton cycle for seawater desalination. J. Clean. Prod. 2018, 196, 889-901. [CrossRef]

19. El-Ghonemy, A.M.K. Performance test of a sea water multi-stage flash distillation plant: Case study. Alex. Eng. J. 2018, 57, 2401-2413. [CrossRef]

20. Khoshrou, I.; Nasr, M.R.J.; Bakhtari, K. New opportunities in mass and energy consumption of the Multi-Stage Flash Distillation type of brackish water desalination process. Sol. Energy 2017, 153, 115-125. [CrossRef]

21. Mahdi, T.; Ahmad, A.; Ripin, A.; Nasef, M.M. Separation of Azeotropic Mixture Using Multi-stage Ultrasound-Assisted Flash Distillation. Chem. Prod. Process Model. 2015, 10, 237-242. [CrossRef]

22. Shen, J.B.; Xing, Z.W.; Wang, X.L.; He, Z.L. Analysis of a single-effect mechanical vapor compression desalination system using water injected twin screw compressors. Desalination 2014, 333, 146-153. [CrossRef]

23. Shen, J.B.; Xing, Z.W.; Zhang, K.; He, Z.L.; Wang, X.L. Development of a water-injected twin-screw compressor for mechanical vapor compression desalination systems. Appl. Therm. Eng. 2016, 95, 125-135. [CrossRef]

24. Askalany, A.A. Innovative mechanical vapor compression adsorption desalination (MVC-AD) system. Appl. Therm. Eng. 2016, 106, 286-292. [CrossRef]

25. Choi, W.; Choi, J.; Bang, J.; Lee, J.H. Layer-by-Layer Assembly of Graphene Oxide Nanosheets on Polyamide Membranes for Durable Reverse-Osmosis Applications. ACS Appl. Mater. Interfaces 2013, 5, 12510-12519. [CrossRef] 
26. Safarpour, M.; Khataee, A.; Vatanpour, V. Thin film nanocomposite reverse osmosis membrane modified by reduced graphene oxide/TiO2 with improved desalination performance. J. Membr. Sci. 2015, 489, 43-54. [CrossRef]

27. Duan, J.T.; Pan, Y.C.; Pacheco, F.; Litwiller, E.; Lai, Z.P.; Pinnau, I. High-performance polyamide thin-film-nanocomposite reverse osmosis membranes containing hydrophobic zeolitic imidazolate framework-8. J. Membr. Sci. 2015, 476, 303-310. [CrossRef]

28. Shaffer, D.L.; Werber, J.R.; Jaramillo, H.; Lin, S.H.; Elimelech, M. Forward osmosis: Where are we now? Desalination 2015, 356, 271-284. [CrossRef]

29. Coday, B.D.; Xu, P.; Beaudry, E.G.; Herron, J.; Lampi, K.; Hancock, N.T.; Cath, T.Y. The sweet spot of forward osmosis: Treatment of produced water, drilling wastewater, and other complex and difficult liquid streams. Desalination 2014, 333, 23-35. [CrossRef]

30. Emadzadeh, D.; Lau, W.J.; Matsuura, T.; Rahbari-Sisakht, M.; Ismail, A.F. A novel thin film composite forward osmosis membrane prepared from PSf-TiO2 nanocomposite substrate for water desalination. Chem. Eng. J. 2014, 237, 70-80. [CrossRef]

31. Drioli, E.; Ali, A.; Macedonio, F. Membrane distillation: Recent developments and perspectives. Desalination 2015, 356, 56-84. [CrossRef]

32. Wang, P.; Chung, T.S. Recent advances in membrane distillation processes: Membrane development, configuration design and application exploring. J. Membr. Sci. 2015, 474, 39-56. [CrossRef]

33. Camacho, L.M.; Dumee, L.; Zhang, J.H.; Li, J.D.; Duke, M.; Gomez, J.; Gray, S. Advances in Membrane Distillation for Water Desalination and Purification Applications. Water 2013, 5, 94-196. [CrossRef]

34. Gahlot, S.; Sharma, P.P.; Gupta, H.; Kulshrestha, V.; Jha, P.K. Preparation of graphene oxide nano-composite ion-exchange membranes for desalination application. RSC Adv. 2014, 4, 24662-24670. [CrossRef]

35. Hilal, N.; Kochkodan, V.; Al Abdulgader, H.; Johnson, D. A combined ion exchange-nanofiltration process for water desalination: II. Membrane selection. Desalination 2015, 363, 51-57. [CrossRef]

36. Wang, T.; Yu, S.L.; Hou, L.A. Impacts of HPAM molecular weights on desalination performance of ion exchange membranes and fouling mechanism. Desalination 2017, 404, 50-58. [CrossRef]

37. Zhang, C.Y.; He, D.; Ma, J.X.; Tang, W.W.; Waite, T.D. Faradaic reactions in capacitive deionization (CDI)_Problems and possibilities: A review. Water Res. 2018, 128, 314-330. [CrossRef]

38. Huang, Z.H.; Yang, Z.Y.; Kang, F.Y.; Inagaki, M. Carbon electrodes for capacitive deionization. J. Mater. Chem. A 2017, 5, 470-496. [CrossRef]

39. Khan, Z.U.; Yan, T.T.; Shi, L.Y.; Zhang, D.S. Improved capacitive deionization by using 3D intercalated graphene sheet-sphere nanocomposite architectures. Environ. Sci. Nano 2018, 5, 980-991. [CrossRef]

40. Ahmed, M.A.; Tewari, S. Capacitive deionization: Processes, materials and state of the technology. J. Electroanal. Chem. 2018, 813, 178-192. [CrossRef]

41. Gao, X.; Omosebi, A.; Ma, Z.; Zhu, F.; Landon, J.; Ghorbanian, M.; Kernd, N.; Liu, K. Capacitive deionization using symmetric carbon electrode pairs. Environ. Sci. Water Res. Technol. 2019, 5, 660-671. [CrossRef]

42. Porada, S.; Borchardt, L.; Oschatz, M.; Bryjak, M.; Atchison, J.S.; Keesman, K.J.; Kaskel, S.; Biesheuvel, P.M.; Presser, V. Direct prediction of the desalination performance of porous carbon electrodes for capacitive deionization. Energy Environ. Sci. 2013, 6, 3700-3712. [CrossRef]

43. Porada, S.; Weinstein, L.; Dash, R.; Van der Wal, A.; Bryjak, M.; Gogotsi, Y.; Biesheuvel, P.M. Water Desalination Using Capacitive Deionization with Microporous Carbon Electrodes. Acs Appl. Mater. Interfaces 2012, 4, 1194-1199. [CrossRef] [PubMed]

44. Li, Y.; Qi, J.W.; Li, J.S.; Shen, J.M.; Liu, Y.X.; Sun, X.Y.; Shen, J.Y.; Han, W.Q.; Wang, L.J. Nitrogen-Doped Hollow Mesoporous Carbon Spheres for Efficient Water Desalination by Capacitive Deionization. ACS Sustain. Chem. Eng. 2017, 5, 6635-6644. [CrossRef]

45. Zhang, W.; Jia, B.P. Toward anti-fouling capacitive deionization by using visible-light reduced TiO2/graphene nanocomposites. MRS Commun. 2015, 5, 613-617. [CrossRef]

46. Li, H.; Zhang, W.; Zou, L.; Pan, L.; Sun, Z. Synthesis of TiO2-graphene composites via visible-light photocatalytic reduction of graphene oxide. J. Mater. Res. 2011, 26, 970-973. [CrossRef]

47. Zhang, W.; Mossad, M.; Yazdi, J.S.; Zou, L.D. A statistical experimental investigation on arsenic removal using capacitive deionization. Desalin. Water Treat. 2016, 57, 3254-3260. [CrossRef] 
48. Wang, T.Y.; Liang, H.; Bai, L.M.; Zhu, X.W.; Gan, Z.D.; Xing, J.J.; Li, G.B.; Aminabhavi, T.M. Adsorption behavior of powdered activated carbon to control capacitive deionization fouling of organic matter. Chem. Eng. J. 2020, 384, 10. [CrossRef]

49. Han, J.L.; Shi, L.Y.; Yan, T.T.; Zhang, J.P.; Zhang, D.S. Removal of ions from saline water using N, P co-doped 3D hierarchical carbon architectures via capacitive deionization. Environ.-Sci. Nano 2018, 5, 2337-2345. [CrossRef]

50. Xu, X.T.; Tan, H.B.; Wang, Z.M.; Wang, C.; Pan, L.K.; Kaneti, Y.V.; Yang, T.; Yamauchi, Y. Extraordinary capacitive deionization performance of highly-ordered mesoporous carbon nano-polyhedra for brackish water desalination. Environ. Sci. Nano 2019, 6, 981-989. [CrossRef]

51. Byles, B.W.; Cullen, D.A.; More, K.L.; Pomerantseva, E. Tunnel structured manganese oxide nanowires as redox active electrodes for hybrid capacitive deionization. Nano Energy 2018, 44, 476-488. [CrossRef]

52. Wu, T.T.; Wang, G.; Wang, S.Y.; Zhan, F.; Fu, Y.; Qiao, H.Y.; Qiu, J.S. Highly Stable Hybrid Capacitive Deionization with a MnO2 Anode and a Positively Charged Cathode. Environ. Sci. Technol. Lett. 2018, 5, 98-102. [CrossRef]

53. Divyapriya, G.; Vijayakumar, K.K.; Nambi, I. Development of a novel graphene/ $\mathrm{Co}_{3} \mathrm{O}_{4} \operatorname{composite}$ for hybrid capacitive deionization system. Desalination 2019, 451, 102-110. [CrossRef]

54. Avraham, E.; Noked, M.; Bouhadana, Y.; Soffer, A.; Aurbach, D. Limitations of Charge Efficiency in Capacitive Deionization II. On the Behavior of CDI Cells Comprising Two Activated Carbon Electrodes. J. Electrochem. Soc. 2009, 156, P157-P162. [CrossRef]

55. Xu, P.; Drewes, J.E.; Heil, D.; Wang, G. Treatment of brackish produced water using carbon aerogel-based capacitive deionization technology. Water Res. 2008, 42, 2605-2617. [CrossRef]

56. Sussz, M.E. Size-Based Ion Selectivity of Micropore Electric Double Layers in Capacitive Deionization Electrodes. J. Electrochem. Soc. 2017, 164, E270-E275. [CrossRef]

57. Liu, P.Y.; Wang, H.; Yan, T.T.; Zhang, J.P.; Shi, L.Y.; Zhang, D.S. Grafting sulfonic and amine functional groups on 3D graphene for improved capacitive deionization. J. Mater. Chem. A 2016, 4, 5303-5313. [CrossRef]

58. Wu, T.T.; Wang, G.; Dong, Q.; Qian, B.Q.; Meng, Y.L.; Qiu, J.S. Asymmetric capacitive deionization utilizing nitric acid treated activated carbon fiber as the cathode. Electrochim. Acta 2015, 176, 426-433. [CrossRef]

59. Guo, Z.; Ma, Y.; Dong, X.; Hou, M.; Wang, Y.; Xia, Y. Integrating Desalination and Energy Storage via Saltwater-based Hybrid Sodium-ion Supercapacitor. Chemsuschem 2018, 11, 1741-1745. [CrossRef]

60. Ahirrao, D.J.; Tambat, S.; Pandit, A.B.; Jha, N. Sweet-Lime-Peels-Derived Activated-Carbon-Based Electrode for Highly Efficient Supercapacitor and Flow-Through Water Desalination. ChemistrySelect 2019, 4, 2610-2625. [CrossRef]

61. Pasta, M.; Wessells, C.D.; Cui, Y.; La Mantia, F. A Desalination Battery. Nano Lett. 2012, 12, 839-843. [CrossRef]

62. Chen, Y.W.; Chen, J.F.; Lin, C.H.; Hou, C.H. Integrating a supercapacitor with capacitive deionization for direct energy recovery from the desalination of brackish water. Appl. Energy 2019, 252, 9. [CrossRef]

63. Nam, D.H.; Lumley, M.A.; Choi, K.S. A Desalination Battery Combining $\mathrm{Cu}_{3}\left[\mathrm{Fe}(\mathrm{CN})_{(6)}\right]_{(2)}$ as a Na-Storage Electrode and $\mathrm{Bi}$ as a Cl-Storage Electrode Enabling Membrane-Free Desalination. Chem. Mater. 2019, 31, 1460-1468. [CrossRef]

64. Sarkar, A.; Sarkar, S.; Sarkar, T.; Kumar, P.; Bharadwaj, M.D.; Mitra, S. Rechargeable Sodium-Ion Battery: High-Capacity Ammonium Vanadate Cathode with Enhanced Stability at High Rate. ACS Appl. Mater. Interfaces 2015, 7, 17044-17053. [CrossRef] [PubMed]

65. You, Y.; Manthiram, A. Progress in High-Voltage Cathode Materials for Rechargeable Sodium-Ion Batteries. Adv. Energy Mater. 2018, 8, 11. [CrossRef]

66. Guo, L.; Mo, R.W.; Shi, W.H.; Huang, Y.X.; Leong, Z.Y.; Ding, M.; Chen, F.M.; Yang, H.Y. A Prussian blue anode for high performance electrochemical deionization promoted by the faradaic mechanism. Nanoscale 2017, 9, 13305-13312. [CrossRef]

67. Chayambuka, K.; Mulder, G.; Danilov, D.L.; Notten, P.H.L. Sodium-Ion Battery Materials and Electrochemical Properties Reviewed. Adv. Energy Mater. 2018, 8, 49. [CrossRef]

68. Wu, Y.; Yu, Y. 2D material as anode for sodium ion batteries: Recent progress and perspectives. Energy Storage Mater. 2019, 16, 323-343. [CrossRef] 
69. Liu, W.L.; Zhi, H.Q.; Yu, X.B. Recent progress in phosphorus based anode materials for lithium/sodium ion batteries. Energy Storage Mater. 2019, 16, 290-322. [CrossRef]

70. Li, X.N.; Zhu, X.B.; Liang, J.W.; Hou, Z.G.; Wang, Y.; Lin, N.; Zhu, Y.C.; Qian, Y.T. Graphene-Supported $\mathrm{NaTi}_{2}\left(\mathrm{PO}_{4}\right)_{(3)}$ as a High Rate Anode Material for Aqueous Sodium Ion Batteries. J. Electrochem. Soc. 2014, 161, A1181-A1187. [CrossRef]

71. Zhang, L.D.; Huang, T.; Yu, A.S. Carbon-coated Na3V2(PO4)(3) nanocomposite as a novel high rate cathode material for aqueous sodium ion batteries. J. Alloy Compd. 2015, 646, 522-527. [CrossRef]

72. Hung, T.F.; Lan, W.H.; Yeh, Y.W.; Chang, W.S.; Yang, C.C.; Lin, J.C. Hydrothermal Synthesis of Sodium Titanium Phosphate Nanoparticles as Efficient Anode Materials for Aqueous Sodium-Ion Batteries. ACS Sustain. Chem. Eng. 2016, 4, 7074-7079. [CrossRef]

73. Song, J.; Gim, J.; Kim, S.; Kang, J.; Mathew, V.; Ahn, D.; Kim, J. A Sodium Manganese Oxide Cathode by Facile Reduction for Sodium Batteries. Chem. Asian J. 2014, 9, 1550-1556. [CrossRef] [PubMed]

74. Lin, Z.P.; Zhao, S.L.; Wu, F.G. Structure and electrochemical properties of layered sodium manganese oxide $\mathrm{Na}_{x} \mathrm{MnO}_{2}$. Mater. Res. Express 2019, 6, 6. [CrossRef]

75. Bucher, N.; Hartung, S.; Gocheva, I.; Cheah, Y.L.; Srinivasan, M.; Hoster, H.E. Combustion-synthesized sodium manganese (cobalt) oxides as cathodes for sodium ion batteries. J. Solid State Electrochem. 2013, 17, 1923-1929. [CrossRef]

76. Shi, W.J.; Zhang, D.; Meng, X.M.; Bao, C.X.; Xu, S.D.; Chen, L.; Wang, X.M.; Liu, S.B.; Wu, Y.C. Low-Strain Reticular Sodium Manganese Oxide as an Ultrastable Cathode for Sodium-Ion Batteries. Acs Appl. Mater. Interfaces 2020, 12, 14174-14184. [CrossRef]

77. Guo, S.H.; Yu, H.J.; Jian, Z.L.; Liu, P.; Zhu, Y.B.; Guo, X.W.; Chen, M.W.; Ishida, M.; Zhou, H.S. A High-Capacity, Low-Cost Layered Sodium Manganese Oxide Material as Cathode for Sodium-Ion Batteries. Chemsuschem 2014, 7, 2115-2119. [CrossRef]

78. Lu, D.; Yao, Z.J.; Li, Y.Q.; Zhong, Y.; Wang, X.L.; Xie, D.; Xia, X.H.; Gu, C.D.; Tu, J.P. Sodium-rich manganese oxide porous microcubes with polypyrrole coating as a superior cathode for sodium ion full batteries. J. Colloid Interface Sci. 2020, 565, 218-226. [CrossRef]

79. Lee, J.; Kim, S.; Kim, C.; Yoon, J. Hybrid capacitive deionization to enhance the desalination performance of capacitive techniques. Energy Environ. Sci. 2014, 7, 3683-3689. [CrossRef]

80. Chen, F.; Huang, Y.X.; Guo, L.; Ding, M.; Yang, H.Y. A dual-ion electrochemistry deionization system based on AgCl-Na ${ }_{0.44} \mathrm{MnO}_{2}$ electrodes. Nanoscale 2017, 9, 10101-10108. [CrossRef]

81. Li, Q.Q.; Wu, J.S.; Xu, J.M.; Dravid, V.P. Synergistic sodiation of cobalt oxide nanoparticles and conductive carbon nanotubes (CNTs) for sodium-ion batteries. J. Mater. Chem. A 2016, 4, 8669-8675. [CrossRef]

82. Lin, S.C.; Lu, Y.T.; Chien, Y.A.; Wang, J.A.; Chen, P.Y.; Ma, C.C.M.; Hu, C.C. Asymmetric supercapacitors based on electrospun carbon nanofiber/sodium-pre-intercalated manganese oxide electrodes with high power and energy densities. J. Power Sources 2018, 393, 1-10. [CrossRef]

83. Chen, B.W.; Wang, Y.F.; Chang, Z.; Wang, X.W.; Li, M.X.; Liu, X.; Zhang, L.X.; Wu, Y.P. Enhanced capacitive desalination of $\mathrm{MnO}_{2}$ by forming composite with multi-walled carbon nanotubes. RSC Adv. 2016, 6, 6730-6736. [CrossRef]

84. Leong, Z.Y.; Yang, H.Y. A Study of $\mathrm{MnO}_{2}$ with Different Crystalline Forms for Pseudocapacitive Desalination. ACS Appl. Mater. Interfaces 2019, 11, 13176-13184. [CrossRef] [PubMed]

85. Xu, S.; Wang, T.; Wang, C.-F.; Chen, C.-W.; Dong, C.-D.; Huang, C.P. The effect of crystal phase of manganese oxide on the capacitive deionization of simple electrolytes. Sci. Total Environ. 2019, 675, 31-40. [CrossRef] [PubMed]

86. Yang, J.P.; Zhou, T.F.; Zhu, R.; Chen, X.Q.; Guo, Z.P.; Fan, J.W.; Liu, H.K.; Zhang, W.X. Highly Ordered Dual Porosity Mesoporous Cobalt Oxide for Sodium-Ion Batteries. Adv. Mater. Interfaces 2016, 3, 7. [CrossRef]

87. Nagata, Y.; Nagao, K.; Deguchi, M.; Sakuda, A.; Hayashi, A.; Tsukasaki, H.; Mori, S.; Tatsumisago, M. Amorphization of Sodium Cobalt Oxide Active Materials for High-Capacity All-Solid-State Sodium Batteries. Chem. Mater. 2018, 30, 6998-7004. [CrossRef]

88. Qi, S.H.; Wu, D.X.; Dong, Y.; Liao, J.Q.; Foster, C.W.; O’Dwyer, C.; Feng, Y.Z.; Liu, C.T.; Ma, J.M. Cobalt-based electrode materials for sodium-ion batteries. Chem. Eng. J. 2019, 370, 185-207. [CrossRef] 
89. Liu, Z.Z.; Yue, Z.S.; Li, H.B. $\mathrm{Na}_{0.71} \mathrm{CoO}_{2}$ promoted sodium uptake via faradaic reaction for highly efficient capacitive deionization. Sep. Purif. Technol. 2020, 234, 10. [CrossRef]

90. Zhou, R.J.; Guo, X.X.; Li, Z.H.; Luo, S.J.; Luo, M. More Ca ${ }^{2+}$, Less Na+: Increase the Desalination Capacity and Performance Stability of $\mathrm{Na}_{x} \mathrm{Ca}_{\mathrm{y}} \mathrm{CoO}_{2}$. ACS Sustain. Chem. Eng. 2019, 7, 14561-14568. [CrossRef]

91. Kitta, M.; Kataoka, R.; Tanaka, S.; Takeichi, N.; Kohyama, M. Spinel-Type Sodium Titanium Oxide: A Promising Sodium-Insertion Material of Sodium-Ion Batteries. ACS Appl. Energ. Mater. 2019, 2, 4345-4353. [CrossRef]

92. Xu, J.; Yang, D.Z.; Liao, X.Z.; He, Y.S.; Ma, Z.F. Electrochemical Performances of Reduced Graphene Oxide/Titanium Dioxide Composites for Sodium-Ion Batteries. Acta Phys. Chim. Sin. 2015, 31, 913-919.

93. Kitta, M.; Kojima, T.; Kataoka, R.; Yazawa, K.; Tada, K. Realizing the Single-Phase Spinel-Type Sodium Titanium Oxide with the $\mathrm{Li}_{4} \mathrm{Ti}_{5} \mathrm{O}_{12}$-like Structure for Building Stable Sodium-Ion Batteries. ACS Appl. Mater. Interfaces 2020, 12, 9322-9331. [CrossRef] [PubMed]

94. Moustafa, H.M.; Obaid, M.; Nassar, M.M.; Abdelkareem, M.A.; Mahmoud, M.S. Titanium dioxide-decorated rGO as an effective electrode for ultrahigh-performance capacitive deionization. Sep. Purif. Technol. 2020, 235, 9. [CrossRef]

95. Yue, Z.S.; Gao, T.; Li, H.B. Robust synthesis of carbon@ $\mathrm{Na}_{4} \mathrm{Ti}_{9} \mathrm{O}_{20}$ core-shell nanotubes for hybrid capacitive deionization with enhanced performance. Desalination 2019, 449, 69-77. [CrossRef]

96. Gu, M.; Kushima, A.; Shao, Y.Y.; Zhang, J.G.; Liu, J.; Browning, N.D.; Li, J.; Wang, C.M. Probing the Failure Mechanism of $\mathrm{SnO}_{2}$ Nanowires for Sodium-Ion Batteries. Nano Lett. 2013, 13, 5203-5211. [CrossRef] [PubMed]

97. Huang, Z.D.; Hou, H.S.; Zou, G.Q.; Chen, J.; Zhang, Y.; Liao, H.X.; Li, S.M.; Ji, X.B. 3D Porous Carbon Encapsulated $\mathrm{SnO}_{2}$ Nanocomposite for Ultrastable Sodium Ion Batteries. Electrochim. Acta 2016, 214, 156-164. [CrossRef]

98. Wang, Y.; Su, D.W.; Wang, C.Y.; Wang, G.X. SnO ${ }_{2} @ M W C N T$ nanocomposite as a high capacity anode material for sodium-ion batteries. Electrochem. Commun. 2013, 29, 8-11. [CrossRef]

99. Li, F.; Luo, G.E.; Chen, W.Y.; Chen, Y.C.; Fang, Y.P.; Zheng, M.T.; Yu, X.Y. Rational Design and Controllable Synthesis of Multishelled $\mathrm{Fe}_{2} \mathrm{O}_{3} @ \mathrm{SnO}_{2} @ \mathrm{C}$ Nanotubes as Advanced Anode Material for Lithium-/Sodium-Ion Batteries. ACS Appl. Mater. Interfaces 2019, 11, 36949-36959. [CrossRef]

100. El-Deen, A.G.; Barakat, N.A.M.; Khalil, K.A.; Motlak, M.; Kim, H.Y. Graphene/SnO 2 nanocomposite as an effective electrode material for saline water desalination using capacitive deionization. Ceram. Int. 2014, 40, 14627-14634. [CrossRef]

101. Yasin, A.S.; Jeong, J.; Mohamed, I.M.A.; Park, C.H.; Kim, C.S. Fabrication of N-doped \& $\mathrm{SnO}_{2}$-incorporated activated carbon to enhance desalination and bio-decontamination performance for capacitive deionization. J. Alloy Compd. 2017, 729, 764-775.

102. Xu, F.; Li, Z.R.; Wu, L.J.; Meng, Q.P.; Xin, H.L.L.; Sun, J.; Ge, B.H.; Sun, L.T.; Zhu, Y.M. In situ TEM probing of crystallization form-dependent sodiation behavior in $\mathrm{ZnO}$ nanowires for sodium-ion batteries. Nano Energy 2016, 30, 771-779. [CrossRef]

103. Teng, Y.Q.; Mo, M.S.; Li, Y.; Xue, J.L.; Zhao, H.L. Amorphous carbon-coated ZnO porous nanosheets: Facile fabrication and application in lithium- and sodium-ion batteries. J. Alloy Compd. 2018, 744, 712-720. [CrossRef]

104. Wang, Y.; Deng, Q.J.; Xue, W.D.; Jian, Z.; Zhao, R.; Wang, J.J. ZnO/rGO/C composites derived from metal-organic framework as advanced anode materials for Li-ion and Na-ion batteries. J. Mater. Sci. 2018, 53, 6785-6795. [CrossRef]

105. Liu, J.Y.; Lu, M.; Yang, J.M.; Cheng, J.; Cai, W.S. Capacitive desalination of ZnO/activated carbon asymmetric capacitor and mechanism analysis. Electrochim. Acta 2015, 151, 312-318. [CrossRef]

106. Arora, N.; Banat, F.; Bharath, G.; Alhseinat, E. Capacitive deionization of $\mathrm{NaCl}$ from saline solution using graphene/CNTs/ZnO NPs based electrodes. J. Phys. D Appl. Phys. 2019, 52, 12. [CrossRef]

107. Qi, S.H.; Xu, B.L.; Tiong, V.T.; Hu, J.; Ma, J.M. Progress on iron oxides and chalcogenides as anodes for sodium-ion batteries. Chem. Eng. J. 2020, 379, 32. [CrossRef]

108. Ni, J.F.; Sun, M.L.; Li, L. Highly Efficient Sodium Storage in Iron Oxide Nanotube Arrays Enabled by Built-In Electric Field. Adv. Mater. 2019, 31, 7. [CrossRef] 
109. Valvo, M.; Lindgren, F.; Lafont, U.; Bjorefors, F.; Edstrom, K. Towards more sustainable negative electrodes in Na-ion batteries via nanostructured iron oxide. J. Power Sources 2014, 245, 967-978. [CrossRef]

110. Li, H.B.; Leong, Z.Y.; Shi, W.H.; Zhang, J.; Chen, T.P.; Yang, H.Y. Hydrothermally synthesized graphene and $\mathrm{Fe}_{3} \mathrm{O}_{4}$ nanocomposites for high performance capacitive deionization. RSC Adv. 2016, 6, 11967-11972. [CrossRef]

111. Trinh, N.T.; Chung, S.; Lee, J.K.; Lee, J. Development of high quality $\mathrm{Fe}_{3} \mathrm{O}_{4} / \mathrm{rGO}$ composited electrode for low energy water treatment. J. Energy Chem. 2016, 25, 354-360. [CrossRef]

112. Zhang, X.Q.; Zhao, Y.C.; Wang, C.G.; Li, X.; Liu, J.D.; Yue, G.H.; Zhou, Z.D. Facile synthesis of hollow urchin-like $\mathrm{NiCo}_{2} \mathrm{O}_{4}$ microspheres for high-performance sodium-ion batteries. J. Mater. Sci. 2016, 51, 9296-9305. [CrossRef]

113. Wang, X.H.; Fang, Y.; Shi, B.; Huang, F.F.; Rong, F.; Que, R.H. Three-dimensional $\mathrm{NiCo}_{2} \mathrm{O}_{4} @ \mathrm{NiCo}_{2} \mathrm{O}_{4}$ core-shell nanocones arrays for high-performance supercapacitors. Chem. Eng. J. 2018, 344, 311-319. [CrossRef]

114. Wu, Z.B.; Zhu, Y.R.; Ji, X.B. NiCo2O4-based materials for electrochemical supercapacitors. J. Mater. Chem. A 2014, 2, 14759-14772. [CrossRef]

115. Wei, T.Y.; Chen, C.H.; Chien, H.C.; Lu, S.Y.; Hu, C.C. A Cost-Effective Supercapacitor Material of Ultrahigh Specific Capacitances: Spinel Nickel Cobaltite Aerogels from an Epoxide-Driven Sol-Gel Process. Adv. Mater. 2010, 22, 347-351. [CrossRef] [PubMed]

116. Liu, Z.Z.; Xi, W.; Li, H.B. The feasibility of hollow echinus-like $\mathrm{NiCo}_{2} \mathrm{O}_{4}$ nanocrystals for hybrid capacitive deionization. Environ. Sci. Water Res. Technol. 2020, 6, 283-289. [CrossRef]

117. Liu, Y.C.; Zhang, N.; Yu, C.M.; Jiao, L.F.; Chen, J. $\mathrm{MnFe}_{2} \mathrm{O}_{4} @ \mathrm{C}$ Nanofibers as High-Performance Anode for Sodium-Ion Batteries. Nano Lett. 2016, 16, 3321-3328. [CrossRef]

118. Geng, L.; Yan, F.F.; Dong, C.H.; An, C.H. Design and Regulation of Novel $\mathrm{MnFe}_{2} \mathrm{O}_{4} @ \mathrm{C}$ Nanowires as High Performance Electrode for Supercapacitor. Nanomaterials 2019, 9, 777. [CrossRef]

119. Kogularasu, S.; Akilarasan, M.; Chen, S.M.; Elaiyappillai, E.; Johnson, P.M.; Chen, T.W.; Al-Hemaid, F.M.A.; Ali, M.A.; Elshikh, M.S. A comparative study on conventionally prepared MnFe2O4 nanospheres and template-synthesized novel $\mathrm{MnFe}_{2} \mathrm{O}_{4}$ nano-agglomerates as the electrodes for biosensing of mercury contaminations and supercapacitor applications. Electrochim. Acta 2018, 290, 533-543. [CrossRef]

120. Kuo, S.L.; Lee, J.F.; Wu, N.L. Study on pseudocapacitance mechanism of aqueous $\mathrm{MnFe}_{2} \mathrm{O}_{4}$ supercapacitor. J. Electrochem. Soc. 2007, 154, A34-A38. [CrossRef]

121. Younes, H.; Zou, L.D. Asymmetric configuration of pseudocapacitive composite and rGO electrodes for enhanced capacitive deionization. Environ. Sci. Water Res. Technol. 2020, 6, 392-403. [CrossRef]

122. Anantharamulu, N.; Rao, K.K.; Rambabu, G.; Kumar, B.V.; Radha, V.; Vithal, M. A wide-ranging review on Nasicon type materials. J. Mater. Sci. 2011, 46, 2821-2837. [CrossRef]

123. Gu, Z.Y.; Guo, J.Z.; Yang, Y.; Zhao, X.X.; Yang, X.; Nie, X.J.; He, X.Y.; Wu, X.L. Research Progress on NASICON-Type Cathode Materials for Sodium Ion Batteries. Chin. J. Inorg. Chem. 2019, 35, 1535-1550.

124. Zhang, Q.C.; Man, P.; He, B.; Li, C.W.; Li, Q.L.; Pan, Z.H.; Wang, Z.X.; Yang, J.; Wang, Z.; Zhou, Z.Y.; et al. Binder-free $\mathrm{NaTi}_{2}\left(\mathrm{PO}_{4}\right)_{(3)}$ anodes for high-performance coaxial-fiber aqueous rechargeable sodium-ion batteries. Nano Energy 2020, 67, 8. [CrossRef]

125. Lei, P.; Li, S.J.; Luo, D.X.; Huang, Y.X.; Tian, G.R.; Xiang, X.D. Fabricating a carbon-encapsulated $\mathrm{NaTi}_{2}\left(\mathrm{PO}_{4}\right)_{(3)}$ framework as a robust anode material for aqueous sodium-ion batteries. J. Electroanal. Chem. 2019, 847, 8. [CrossRef]

126. Shao, M.M.; Wang, B.; Liu, M.C.; Wu, C.; Ke, F.S.; Ai, X.P.; Yang, H.X.; Qian, J.F. A High-Voltage and Cycle Stable Aqueous Rechargeable Na-Ion Battery Based on $\mathrm{Na}_{2} \mathrm{Zn}_{3}\left[\mathrm{Fe}(\mathrm{CN})_{(6)}\right]_{(2)}-\mathrm{NaTi}_{2}\left(\mathrm{PO}_{4}\right)_{(3)}$ Intercalation Chemistry. ACS Appl. Energy Mater. 2019, 2, 5809-5815. [CrossRef]

127. Liu, Z.X.; Pang, G.; Dong, S.Y.; Zhang, Y.D.; Mi, C.H.; Zhang, X.G. An aqueous rechargeable sodium-magnesium mixed ion battery based on $\mathrm{NaTi}_{2}\left(\mathrm{PO}_{4}\right)_{(3)}-\mathrm{MnO}_{2}$ system. Electrochim. Acta 2019, 311, 1-7. [CrossRef]

128. Huang, Y.X.; Chen, F.M.; Guo, L.; Yang, H.Y. Ultrahigh performance of a novel electrochemical deionization system based on a $\mathrm{NaTi}_{2}\left(\mathrm{PO}_{4}\right)\left({ }_{3}\right) / \mathrm{rGO}$ nanocomposite. J. Mater. Chem. A 2017, 5, 18157-18165. [CrossRef]

129. Pei, J.; Geng, H.B.; Ang, H.X.; Zhang, L.L.; Wei, H.X.; Cao, X.Q.; Zheng, J.W.; Gu, H.W. Three-dimensional nitrogen and sulfur co-doped holey-reduced graphene oxide frameworks anchored with $\mathrm{MoO}_{2}$ nanodots for advanced rechargeable lithium-ion batteries. Nanotechnology 2018, 29, 11. [CrossRef] 
130. Yang, Z.X.; Qian, K.; Lv, J.; Yan, W.H.; Liu, J.H.; Ai, J.W.; Zhang, Y.X.; Guo, T.L.; Zhou, X.T.; Xu, S.; et al. Encapsulation of $\mathrm{Fe}_{3} \mathrm{O}_{4}$ Nanoparticles into N, S co-Doped Graphene Sheets with Greatly Enhanced Electrochemical Performance. Sci. Rep. 2016, 6, 10. [CrossRef]

131. Liang, S.J.; Han, C.L.; Meng, Q.H.; Tian, G.Y. Nitrogen and sulfur co-doped $\mathrm{NaTi}_{2}\left(\mathrm{PO}_{4}\right)_{(3)} /$ hole graphene composite as high-performance electrosorption electrodes for hybrid capacitive deionization. J. Mater. Sci. 2020, 55, 6017-6029. [CrossRef]

132. Huang, Y.X.; Chen, F.M.; Guo, L.; Zhang, J.; Chen, T.P.; Yang, H.Y. Low energy consumption dual-ion electrochemical deionization system using $\mathrm{NaTi}_{2}\left(\mathrm{PO}_{4}\right)_{(3)}$-AgNPs electrodes. Desalination 2019, 451, 241-247. [CrossRef]

133. Wang, L.B.; Mu, C.N.; Li, H.X.; Li, F.J. A dual-function battery for desalination and energy storage. Inorg. Chem. Front. 2018, 5, 2522-2526. [CrossRef]

134. Zhang, X.X.; Ma, J.; Hu, P.; Chen, B.B.; Lu, C.L.; Zhou, X.H.; Han, P.X.; Chen, L.H.; Cui, G.L. An insight into failure mechanism of NASICON-structured $\mathrm{Na}_{3} \mathrm{~V}_{2}\left(\mathrm{PO}_{4}\right)_{(3)}$ in hybrid aqueous rechargeable battery. J. Energy Chem. 2019, 32, 1-7. [CrossRef]

135. Islam, S.; Alfaruqi, M.H.; Putro, D.Y.; Mathew, V.; Kim, S.; Jo, J.; Kim, S.; Sun, Y.K.; Kim, K.; Kim, J. Pyrosynthesis of $\mathrm{Na}_{3} \mathrm{~V}_{2}\left(\mathrm{PO}_{4}\right)_{(3)} @ \mathrm{C}$ Cathodes for Safe and Low-Cost Aqueous Hybrid Batteries. Chemsuschem 2018, 11, 2239-2247. [CrossRef] [PubMed]

136. Li, G.L.; Yang, Z.; Jiang, Y.; Zhang, W.X.; Huang, Y.H. Hybrid aqueous battery based on $\mathrm{Na}_{3} \mathrm{~V}_{2}\left(\mathrm{PO}_{4}\right)_{(3)} / \mathrm{C}$ cathode and zinc anode for potential large-scale energy storage. J. Power Sources 2016, 308, 52-57. [CrossRef]

137. Cao, J.L.; Wang, Y.; Wang, L.; Yu, F.; Ma, J. $\mathrm{Na}_{3} \mathrm{~V}_{2}\left(\mathrm{PO}_{4}\right)_{(3)} @ \mathrm{C}$ as Faradaic Electrodes in Capacitive Deionization for High-Performance Desalination. Nano Lett. 2019, 19, 823-828. [CrossRef]

138. Zhang, W.; Liu, Y.T.; Chen, C.J.; Li, Z.; Huang, Y.H.; Hu, X.L. Flexible and Binder-Free Electrodes of Sb/rGO and $\mathrm{Na}_{3} \mathrm{~V}_{2}\left(\mathrm{PO}_{4}\right)_{(3)} / \mathrm{rGO}$ Nanocomposites for Sodium-Ion Batteries. Small 2015, 11, 3822-3829. [CrossRef] [PubMed]

139. Zhao, W.Y.; Ding, M.; Guo, L.; Yang, H.Y. Dual-Ion Electrochemical Deionization System with Binder-Free Aerogel Electrodes. Small 2019, 15, 8. [CrossRef]

140. Jung, Y.H.; Lim, C.H.; Kim, J.H.; Kim, D.K. $\mathrm{Na}_{2} \mathrm{FeP}_{2} \mathrm{O}_{7}$ as a positive electrode material for rechargeable aqueous sodium-ion batteries. RSC Adv. 2014, 4, 9799-9802. [CrossRef]

141. Kim, S.; Lee, J.; Kim, C.; Yoon, J. Na2FeP2O7 as a Novel Material for Hybrid Capacitive Deionization. Electrochim. Acta 2016, 203, 265-271. [CrossRef]

142. Matos-Peralta, Y.; Antuch, M. Review-Prussian Blue and Its Analogs as Appealing Materials for Electrochemical Sensing and Biosensing. J. Electrochem. Soc. 2019, 167, 9. [CrossRef]

143. Zakaria, M.B.; Chikyow, T. Recent advances in Prussian blue and Prussian blue analogues: Synthesis and thermal treatments. Coord. Chem. Rev. 2017, 352, 328-345. [CrossRef]

144. Liu, Q.N.; Hu, Z.; Chen, M.Z.; Zou, C.; Jin, H.L.; Wang, S.; Chou, S.L.; Liu, Y.; Dou, S.X. The Cathode Choice for Commercialization of Sodium-Ion Batteries: Layered Transition Metal Oxides versus Prussian Blue Analogs. Adv. Funct. Mater. 2020, 30, 15. [CrossRef]

145. Yin, J.W.; Shen, Y.; Li, C.; Fan, C.Y.; Sun, S.X.; Liu, Y.; Peng, J.; Qing, L.; Han, J.T. In Situ Self-Assembly of Core-Shell Multimetal Prussian Blue Analogues for High-Performance Sodium-Ion Batteries. Chemsuschem 2019, 12, 4786-4790. [CrossRef] [PubMed]

146. Lee, J.; Kim, S.; Yoon, J. Rocking Chair Desalination Battery Based on Prussian Blue Electrodes. ACS Omega 2017, 2, 1653-1659. [CrossRef]

147. Porada, S.; Shrivastava, A.; Bukowska, P.; Biesheuvel, P.M.; Smith, K.C. Nickel Hexacyanoferrate Electrodes for Continuous Cation Intercalation Desalination of Brackish Water. Electrochim. Acta 2017, 255, 369-378. [CrossRef]

148. Zhang, J.S.; Zhang, D.P.; Niu, F.; Li, X.T.; Wang, C.S.; Yang, J. FeFe(CN) (6) Nanocubes as a Bipolar Electrode Material in Aqueous Symmetric Sodium-Ion Batteries. ChemPlusChem 2017, 82, 1170-1173. [CrossRef]

149. Wang, Z.Y.; Lu, Y.C. Facile Construction of High-Performance Amorphous FePO4/Carbon Nanomaterials as Cathodes of Lithium-Ion Batteries. ACS Appl. Mater. Interfaces 2019, 11, 13225-13233. [CrossRef] [PubMed]

150. Zhang, Y.Y.; Huang, C.; Min, H.; Shu, H.B.; Gao, P.; Liang, Q.Q.; Yang, X.K.; Liu, L.; Wang, X.Y. Bowl-like double carbon layer architecture of hollow carbon@FePO${ }_{4} @$ reduced graphene oxide composite as high-performance cathodes for sodium and lithium ion batteries. J. Alloy Compd. 2019, 795, 34-44. [CrossRef] 
151. Wang, Y.; Feng, Z.; Laul, D.; Zhu, W.; Provencher, M.; Trudeau, M.L.; Guerfi, A.; Zaghib, K. Ultra-low cost and highly stable hydrated FePO4 anodes for aqueous sodium-ion battery. J. Power Sources 2018, 374, 211-216. [CrossRef]

152. Yang, G.L.; Ding, B.; Wang, J.; Nie, P.; Dou, H.; Zhang, X.G. Excellent cycling stability and superior rate capability of a graphene-amorphous $\mathrm{FePO}_{4}$ porous nanowire hybrid as a cathode material for sodium ion batteries. Nanoscale 2016, 8, 8495-8499. [CrossRef]

153. Guo, L.; Huang, Y.X.; Ding, M.; Leong, Z.Y.; Vafakhah, S.; Yang, H.Y. A high performance electrochemical deionization method to desalinate brackish water with an $\mathrm{FePO}_{4} / \mathrm{RGO}$ nanocomposite. J. Mater. Chem. A 2018, 6, 8901-8908. [CrossRef]

154. Ma, J.; Wang, L.; Yu, F.; Dai, X.H. Mesoporous amorphous $\mathrm{FePO}_{4}$ nanosphere@Graphene as a faradic electrode in capacitive deionization for high-capacity and fast removal of $\mathrm{NaCl}$ from water. Chem. Eng. J. 2019, 370, 938-943. [CrossRef]

155. Wang, Y.; Yang, Y.; Zhang, D.; Wang, Y.; Luo, X.; Liu, X.; Kim, J.-K.; Luo, Y. Inter-overlapped $\mathrm{MoS}_{2} / \mathrm{C}$ composites with large-interlayer-spacing for high-performance sodium-ion batteries. Nanoscale Horizons 2020, 5, 1127-1135. [CrossRef]

156. Zhang, X.D.; Liu, K.L.; Zhang, S.J.; Miao, F.J.; Xiao, W.D.; Shen, Y.L.; Zhang, P.; Wang, Z.; Shao, G.S. Enabling remarkable cycling performance of high-loading $\mathrm{MoS}_{2} @$ Graphene anode for sodium ion batteries with tunable cut-off voltage. J. Power Sources 2020, 458, 10. [CrossRef]

157. Srimuk, P.; Lee, J.; Fleischmann, S.; Choudhury, S.; Presser, V. Faradaic deionization of brackish and sea water via pseudocapacitive cation and anion intercalation into few layered molybdenum disulfide. J. Mater. Chem. A 2017, 5, 15640-15649. [CrossRef]

158. Feifei, J.; Kaige, S.; Bingqiao, Y.; Xian, Z.; Qingmiao, W.; Shaoxian, S. Defect-rich molybdenum disulfide as electrode for enhanced capacitive deionization from water. Desalination 2018, 446, 21-30.

159. Wang, Q.; Jia, F.; Song, S.; Li, Y. Hydrophilic MoS2/Polydopamine (PDA) Nanocomposites as The Electrode for Enhanced Capacitive Deionization. Sep. Purif. Technol. 2019, 236, 116298. [CrossRef]

160. Jiang, Q.; Lei, Y.J.; Liang, H.F.; Xi, K.; Xia, C.; Alshareef, H.N. Review of MXene electrochemical microsupercapacitors. Energy Storage Mater. 2020, 27, 78-95. [CrossRef]

161. Du, L.; Duan, H.H.; Xia, Q.; Jiang, C.; Yan, Y.R.; Wu, S.P. Hybrid Charge-Storage Route to $\mathrm{Nb}_{2} \mathrm{CT}_{\mathrm{x}} \mathrm{MXene}$ as Anode for Sodium-Ion Batteries. ChemistrySelect 2020, 5, 1186-1192. [CrossRef]

162. Meng, J.N.; Zhang, F.F.; Zhang, L.; Liu, L.Y.; Chen, J.T.; Yang, B.J.; Yan, X.B. Rolling up MXene sheets into scrolls to promote their anode performance in lithium-ion batteries. J. Energy Chem. 2020, 46, 256-263. [CrossRef]

163. Wang, X.; Guo, L.; Leong, Z.Y.; Mo, R.; Sun, L.; Yang, H.Y. Ar plasma modification of 2D MXene $\mathrm{Ti}_{3} \mathrm{C}_{2} \mathrm{~T}_{\mathrm{X}}$ nanosheets for efficient capacitive desalination. Flatchem 2018, 8, 17-24.

164. Bao, W.Z.; Tang, X.; Guo, X.; Choi, S.; Wang, C.Y.; Gogotsi, Y.; Wang, G.X. Porous Cryo-Dried MXene for Efficient Capacitive Deionization. Joule 2018, 2, 778-787. [CrossRef]

165. Li, C.X.; Wang, S.Y.; Wang, G.; Wang, S.F.; Che, X.P.; Li, D.Z.; Qiu, J.S. $\mathrm{NH}_{4} \mathrm{~V}_{4} \mathrm{O}_{10} / \mathrm{rGO}$ Composite as a high-performance electrode material for hybrid capacitive deionization. Environ. Sci. Water Res. Technol. 2020, 6, 303-311. [CrossRef]

166. Bubulinca, C.; Sapurina, I.; Kazantseva, N.E.; Vilcakova, J.; Cheng, Q.; Saha, P. Fabrication of a flexible binder-free lithium manganese oxide cathode for secondary Li-Ion batteries. J. Phys. Chem. Solids 2020, 137, 9. [CrossRef]

167. Berhe, G.B.; Su, W.N.; Huang, C.J.; Hagos, T.M.; Hagos, T.T.; Bezabh, H.K.; Weret, M.A.; Abrha, L.H.; Yang, Y.W.; Hwang, B.J. A new class of lithium-ion battery using sulfurized carbon anode from polyacrylonitrile and lithium manganese oxide cathode. J. Power Sources 2019, 434, 9. [CrossRef]

168. Wang, K.; Wan, J.J.; Xiang, Y.X.; Zhu, J.P.; Leng, Q.Y.; Wang, M.; Xu, L.M.; Yang, Y. Recent advances and historical developments of high voltage lithium cobalt oxide materials for rechargeable Li-ion batteries. J. Power Sources 2020, 460, 16. [CrossRef]

169. Zhao, S.Q.; Zhang, W.X.; Li, G.M.; Zhu, H.C.; Huang, J.W.; He, W.Z. Ultrasonic renovating and coating modifying spent lithium cobalt oxide from the cathode for the recovery and sustainable utilization of lithium-ion battery. J. Clean. Prod. 2020, 257, 11. [CrossRef] 
170. Joo, S.H.; Shin, D.J.; Oh, C.; Wang, J.P.; Senanayake, G.; Shin, S.M. Selective extraction and separation of nickel from cobalt, manganese and lithium in pre-treated leach liquors of ternary cathode material of spent lithium-ion batteries using synergism caused by Versatic 10 acid and LIX 84-I. Hydrometallurgy 2016, 159, 65-74. [CrossRef]

171. Song, B.F.; Dhanabalan, A.; Biswal, S.L. Evaluating the capacity ratio and prelithiation strategies for extending cyclability in porous silicon composite anodes and lithium iron phosphate cathodes for high capacity lithium-ion batteries. J. Energy Storage 2020, 28, 8. [CrossRef]

172. Liu, Y.Y.; Liu, H.; An, L.W.; Zhao, X.X.; Liang, G.C. Blended spherical lithium iron phosphate cathodes for high energy density lithium-ion batteries. Ionics 2019, 25, 61-69. [CrossRef]

173. Guo, L.; Kong, D.Z.; Pam, M.E.; Huang, S.Z.; Ding, M.; Shang, Y.; Gu, C.D.; Huang, Y.X.; Yang, H.Y. The efficient faradaic $\mathrm{Li}_{4} \mathrm{Ti}_{5} \mathrm{O}_{12} @ \mathrm{C}$ electrode exceeds the membrane capacitive desalination performance. J. Mater. Chem. A 2019, 7, 8912-8921. [CrossRef]

174. Genovese, M.; Lian, K. Polyoxometalate modified inorganic-organic nanocomposite materials for energy storage applications: A review. Curr. Opin. Solid State Mater. Sci. 2015, 19, 126-137. [CrossRef]

175. Zhou, Y.; Guo, Z.J.; Hou, W.; Wang, Q.; Wang, J. Polyoxometalate-based phase transfer catalysis for liquid-solid organic reactions: A review. Catal. Sci. Technol. 2015, 5, 4324-4335. [CrossRef]

176. Jia, X.Y.; Wang, J.X.; Hu, H.B.; Song, Y.F. Three-Dimensional Carbon Framework Anchored Polyoxometalate as a High-Performance Anode for Lithium-Ion Batteries. Chem. Eur. J. 2020, 26, 5257-5263. [CrossRef]

177. Yang, X.; Zhu, P.P.; Ma, X.L.; Li, W.J.; Tan, Z.L.; Sha, J.Q. Graphite-like polyoxometalate-based metal-organic framework as an efficient anode for lithium ion batteries. Crystengcomm 2020, 22, 1340-1345. [CrossRef]

178. Liu, H.; Zhang, J.; Xu, X.X.; Wang, Q. A Polyoxometalate-Based Binder-Free Capacitive Deionization Electrode for Highly Efficient Sea Water Desalination. Chem. Eur. J. 2020, 26, 4403-4409. [CrossRef]

179. Liu, N.; Zhang, Y.; Xu, X.; Wang, Y. A binder free hierarchical mixed capacitive deionization electrode based on a polyoxometalate and polypyrrole for brackish water desalination. Dalton Trans. 2020, 49, 6321-6327. [CrossRef]

180. Zhang, Z.S.; Shen, K.X.; Zhou, Y.; Hou, X.H.; Ru, Q.; He, Q.Y.; Su, C.Y.; Sun, L.F.; Aung, S.H.; Chen, F.M. The composite electrode of Bi@carbon-texture derived from metal-organic frameworks for aqueous chloride ion battery. Ionics 2020, 26, 2395-2403. [CrossRef]

181. Yin, Q.; Luo, J.N.; Zhang, J.; Zhang, S.X.; Han, J.B.; Lin, Y.J.; Zhou, J.S.; Zheng, L.R.; Wei, M. Ultralong-Life Chloride Ion Batteries Achieved by the Synergistic Contribution of Intralayer Metals in Layered Double Hydroxides. Adv. Funct. Mater. 2020, 30, 8. [CrossRef]

182. Zhao, X.Y.; Ren, S.H.; Bruns, M.; Fichtner, M. Chloride ion battery: A new member in the rechargeable battery family. J. Power Sources 2014, 245, 706-711. [CrossRef]

183. Chen, F.M.; Leong, Z.Y.; Yang, H.Y. An aqueous rechargeable chloride ion battery. Energy Storage Mater. 2017, 7, 189-194. [CrossRef]

184. Chang, J.J.; Duan, F.; Su, C.L.; Li, Y.P.; Cao, H.B. Removal of chloride ions using a bismuth electrode in capacitive deionization (CDI). Environ. Sci. Water Res. Technol. 2020, 6, 373-382. [CrossRef]

185. Nam, D.H.; Choi, K.S. Electrochemical Desalination Using Bi/BiOCl Electrodialysis Cells. ACS Sustain. Chem. Eng. 2018, 6, 15455-15462. [CrossRef]

186. Chen, F.M.; Huang, Y.X.; Guo, L.; Sun, L.F.; Wang, Y.; Yang, H.Y. Dual-ions electrochemical deionization: A desalination generator. Energy Environ. Sci. 2017, 10, 2081-2089. [CrossRef]

187. Kim, K.; Hwang, S.M.; Park, J.S.; Han, J.; Kim, J.; Kim, Y. Highly improved voltage efficiency of seawater battery by use of chloride ion capturing electrode. J. Power Sources 2016, 313, 46-50. [CrossRef]

188. Tsai, Y.C.; Doong, R.A. Hierarchically ordered mesoporous carbons and silver nanoparticles as asymmetric electrodes for highly efficient capacitive deionization. Desalination 2016, 398, 171-179. [CrossRef]

189. Zhang, H.; Zhang, W.X.; Shen, J.M.; Li, Y.; Yan, X.; Qi, J.W.; Sun, X.Y.; Shen, J.Y.; Han, W.Q.; Wang, L.J.; et al. Ag-doped hollow ZIFs-derived nanoporous carbon for efficient hybrid capacitive deionization. Desalination 2020, 473, 9. [CrossRef]

190. Ahn, J.; Lee, J.; Kim, S.; Kim, C.; Lee, J.; Biesheuvel, P.M.; Yoon, J. High performance electrochemical saline water desalination using silver and silver-chloride electrodes. Desalination 2020, 476, 7. [CrossRef] 
191. Srimuk, P.; Husmann, S.; Presser, V. Low voltage operation of a silver/silver chloride battery with high desalination capacity in seawater. RSC Adv. 2019, 9, 14849-14858. [CrossRef]

192. Naveen, M.H.; Gurudatt, N.G.; Shim, Y.B. Applications of conducting polymer composites to electrochemical sensors: A review. Appl. Mater. Today 2017, 9, 419-433. [CrossRef]

193. Abdelhamid, M.E.; O'Mullane, A.P.; Snook, G.A. Storing energy in plastics: A review on conducting polymers \& their role in electrochemical energy storage. RSC Adv. 2015, 5, 11611-11626.

194. Oka, K.; Strietzel, C.; Emanuelsson, R.; Nishide, H.; Oyaizu, K.; Stromme, M.; Sjodin, M. Conducting Redox Polymer as a Robust Organic Electrode-Active Material in Acidic Aqueous Electrolyte towards Polymer-Air Secondary Batteries. Chemsuschem 2020, 13, 2280-2285. [CrossRef] [PubMed]

195. Hudak, N.S. Chloroaluminate-Doped Conducting Polymers as Positive Electrodes in Rechargeable Aluminum Batteries. J. Phys. Chem. C 2014, 118, 5203-5215. [CrossRef]

196. Wang, Z.M.; Xu, X.T.; Kim, J.; Malgras, V.; Mo, R.; Li, C.L.; Lin, Y.Z.; Tan, H.B.; Tang, J.; Pan, L.K.; et al. Nanoarchitectured metal-organic framework/polypyrrole hybrids for brackish water desalination using capacitive deionization. Mater. Horizons 2019, 6, 1433-1437. [CrossRef]

197. Zhang, Y.J.; Wang, Y.; Xu, S.C.; Wang, J.X.; Wang, Z.; Wang, S.C. Polypyrrole nanowire modified graphite (PPy/G) electrode used in capacitive deionization. Synth. Met. 2010, 160, 1392-1396. [CrossRef]

198. Feng, J.T.; Zhang, Q.; Wang, J.J.; Yang, H.H.; Xu, H.; Yan, W. Application of chemically synthesized polypyrrole with hydro-sponge characteristic as electrode in water desalination. RSC Adv. 2015, 5, 71593-71600. [CrossRef]

199. Wang, Y.; Han, X.Y.; Wang, R.G.; Xu, S.C.; Wang, J.X. Preparation optimization on the coating-type polypyrrole/carbon nanotube composite electrode for capacitive deionization. Electrochim. Acta 2015, 182, 81-88. [CrossRef]

200. Haq, O.U.; Choi, J.-H.; Lee, Y.-S. Synthesis of Ion-Exchange Polypyrrole/Activated Carbon Composites and Their Characterization as Electrodes for Capacitive Deionization. Macromol. Res. 2020, 28, 877-880. [CrossRef]

201. Xu, K.; Liu, Y.H.; An, Z.H.; Xu, G.R.; Gadgil, A.J.; Ruan, G.L. The polymeric conformational effect on capacitive deionization performance of graphene oxide/polypyrrole composite electrode. Desalination 2020, 486, 9. [CrossRef]

202. Huang, Z.Q.; Li, L.; Wang, Y.F.; Zhang, C.; Liu, T.X. Polyaniline/graphene nanocomposites towards high-performance supercapacitors: A review. Compos. Commun. 2018, 8, 83-91. [CrossRef]

203. Sen, T.; Mishra, S.; Shimpi, N.G. Synthesis and sensing applications of polyaniline nanocomposites: A review. RSC Adv. 2016, 6, 42196-42222. [CrossRef]

204. Yan, C.; Kanaththage, Y.W.; Short, R.; Gibson, C.T.; Zou, L.D. Graphene/Polyaniline nanocomposite as electrode material for membrane capacitive deionization. Desalination 2014, 344, 274-279. [CrossRef]

205. Wang, Y.; Wang, R.G.; Xu, S.C.; Liu, Q.; Wang, J.X. Polypyrrole/polyaniline composites with enhanced performance for capacitive deionization. Desalin. Water Treat. 2015, 54, 3248-3256. [CrossRef]

206. Tian, S.C.; Zhang, Z.H.; Zhang, X.H.; Ostrikov, K. Capacitative deionization using commercial activated carbon fiber decorated with polyaniline. J. Colloid Interface Sci. 2019, 537, 247-255. [CrossRef]

207. ul Haq, O.; Choi, J.H.; Lee, Y.S. Synthesis of ion-exchange polyaniline-carbon composite electrodes for capacitive deionization. Desalination 2020, 479, 9.

208. Janoschka, T.; Hager, M.D.; Schubert, U.S. Powering up the Future: Radical Polymers for Battery Applications. Adv. Mater. 2012, 24, 6397-6409. [CrossRef]

209. Zhang, K.; Hu, Y.X.; Wang, L.Z.; Monteiro, M.J.; Jia, Z.F. Pyrene-Functionalized PTMA by NRC for Greater pi-pi Stacking with rGO and Enhanced Electrochemical Properties. ACS Appl. Mater. Interfaces 2017, 9, 34900-34908. [CrossRef]

210. Lopez-Pena, H.A.; Hernandez-Munoz, L.S.; Cardoso, J.; Gonzalez, F.J.; Gonzalez, I.; Frontana, C. Electrochemical and spectroelectrochemical properties of nitroxyl radical species in PTMA, an organic radical polymer. Influence of the microstructure. Electrochem. Commun. 2009, 11, 1369-1372. [CrossRef]

211. Li, Y.Q.; Ding, Z.B.; Li, J.B.; Wang, K.; Lu, T.; Pan, L.K. Novel membrane-free hybrid capacitive deionization with a radical polymer anode for stable desalination. Desalination 2020, 481, 9. [CrossRef] 
212. Hou, X.H.; Liang, Q.; Hu, X.Q.; Zhou, Y.; Ru, Q.; Chen, F.M.; Hu, S.J. Coupling desalination and energy storage with redox flow electrodes. Nanoscale 2018, 10, 12308-12314. [CrossRef] [PubMed]

213. Desai, D.; Beh, E.S.; Sahu, S.; Vedharathinam, V.; van Overmeere, Q.; de Lannoy, C.F.; Jose, A.P.; Volkel, A.R.; Rivest, J.B. Electrochemical Desalination of Seawater and Hypersaline Brines with Coupled Electricity Storage. ACS Energy Lett. 2018, 3, 375-379. [CrossRef]

Publisher's Note: MDPI stays neutral with regard to jurisdictional claims in published maps and institutional affiliations.

(C) 2020 by the authors. Licensee MDPI, Basel, Switzerland. This article is an open access article distributed under the terms and conditions of the Creative Commons Attribution (CC BY) license (http://creativecommons.org/licenses/by/4.0/). 